University of Nebraska - Lincoln

DigitalCommons@University of Nebraska - Lincoln

Faculty Papers and Publications in Animal

Science

Animal Science Department

March 1999

\title{
Responses in Ovulation Rate, Embryonal Survival, and Litter Traits in Swine to 14 Generations of Selection to Increase Litter Size
}

Rodger K. Johnson

University of Nebraska-Lincoln, rjohnson5@unl.edu

Merlyn K. Nielsen

University of Nebraska-Lincoln, mnielsen1@unl.edu

David S. Casey

University of Nebraska-Lincoln

Follow this and additional works at: https://digitalcommons.unl.edu/animalscifacpub

Part of the Animal Sciences Commons

Johnson, Rodger K.; Nielsen, Merlyn K.; and Casey, David S., "Responses in Ovulation Rate, Embryonal Survival, and Litter Traits in Swine to 14 Generations of Selection to Increase Litter Size" (1999). Faculty Papers and Publications in Animal Science. 96.

https://digitalcommons.unl.edu/animalscifacpub/96

This Article is brought to you for free and open access by the Animal Science Department at DigitalCommons@University of Nebraska - Lincoln. It has been accepted for inclusion in Faculty Papers and Publications in Animal Science by an authorized administrator of DigitalCommons@University of Nebraska - Lincoln. 


\title{
Responses in Ovulation Rate, Embryonal Survival, and Litter Traits in Swine to 14 Generations of Selection to Increase Litter Size ${ }^{1}$
}

\author{
Rodger K. J ohnson², Merlyn K. Nielsen, and David S. Casey
}

Department of Animal Science, University of Nebraska, Lincoln 68583-0908

\begin{abstract}
Eleven generations of selection for increased index of ovulation rate and embryonal survival rate, followed by three generations of selection for litter size, were practiced. Laparotomy was used to count corpora lutea and fetuses at $50 \mathrm{~d}$ of gestation. High-indexing gilts, approximately 30\%, were farrowed. Sons of dams in the upper $10 \%$ of the distribution were selected. Selection from Generations 12 to 14 was for increased number of fully formed pigs; replacements were from the largest $25 \%$ of the litters. A randomly selected control line was maintained. Responses at Generation 11 were approximately 7.4 ova and 3.8 fetuses at $50 \mathrm{~d}$ of gestation $(P<.01)$ and 2.3 fully formed pigs $(P<.01)$ and 1.1 live pigs at birth $(P<.05)$. Responses at Generation 14 were three fully formed pigs $(P<.01)$ and 1.4 live pigs $(P<$ $.05)$ per litter. Number of pigs weaned declined ( $P<$
\end{abstract}

.05) in the index line. Total litter weight weaned did not change significantly. Ovulation rate and number of fetuses had positive genetic correlations with number of stillborn pigs per litter. Significantly greater rate of inbreeding and increased litter size at $50 \mathrm{~d}$ of gestation in the select line may have contributed to greater fetal losses in late gestation, greater number of stillborn pigs, and lighter pigs at birth, leading to lower preweaning viability. Heritabilities of traits were between 8 and $25 \%$. Genetic improvement programs should emphasize live-born pigs and perhaps weight of live-born pigs because of undesirable genetic relationships of ovulation rate and number of fetuses with numbers of stillborn and mummified pigs and because birth weight decreased as litter size increased.

Key Words: Pigs, Selection, Ovulation Rate, Embryo Mortality, Litter Size

(01999 American Society of Animal Science All rights reserved.

J. Anim. Sci. 1999. 77:541-557

\section{Introduction}

Litter size in swine is an important component of production efficiency. Industry selection practices in recent years have improved percentage of carcass lean and growth rate more than reproductive traits. Economic value of reproductive traits relative to growth and backfat is expected to increase in the future (Schinckel et al., 1998).

Direct selection for increased litter size in pigs was unsuccessful in one experiment (Ollivier, 1982) but was effective in a line previously selected for increased ovulation rate (Lamberson et al., 1991). Research with mice (Bradford, 1969; Land and Falconer, 1969) and swine (Cunningham et al., 1979; Lamberson et al., 1991) demonstrated that ovulation rate responded to selection, but correlated responses in litter size

\footnotetext{
${ }^{1}$ Published as paper no. 12239, J ournal Ser., Nebraska Agric. Res. Div., Univ. Of Nebraska, Lincoln 68586-0908.

${ }^{2}$ To whom correspondence should be addressed: A218 Animal Sciences.

Received May 11, 1998.

Accepted September 12, 1998.
}

were small. However, Bradford (1969) selected for prenatal survival in mice and litter size increased significantly.

J ohnson et al. (1984) constructed a selection index of ovulation rate and embryonal survival to maximize expected increase in litter size. Utilization of laparotomy at $50 \mathrm{~d}$ of gestation to count corpora lutea and fetuses was proposed to increase selection intensity and to place optimum weight on component traits. Neal et al. (1989) reported responses after five generations of selection. Six additional generations of index selection and three generations of litter size selection were practiced. The objectives of the research reported here were 1 ) to estimate total responses in litter size and its components and in number and weight of pigs weaned and 2) to estimate genetic and phenotypic parameters of traits in the index with the other traits.

\section{Materials and Methods}

Population. The population was a composite of Large White and Landrace. Founder animals included 10 Landrace and 11 Large White boars and 14 
Landrace and 40 Large White females, which were reciprocally mated to produce 54 crossbred litters. One boar from each $F_{1}$ half-sib family and one gilt per litter were randomly selected and mated, avoiding full- and half-sib matings, to produce $42 F_{2}$ generation litters. Three littermate boars from each half-sib $F_{2}$ family were selected randomly and assigned to either a control line ( Line C), an index selection line ( Line I), or a testis size selection line (Line TS). Gilts within each $\mathrm{F}_{2}$ litter were assigned randomly to one of these lines. The selected $\mathrm{F}_{2}$ pigs were mated randomly to produce the $F_{3}$ generation. Selection began from the $\mathrm{F}_{3}$ progeny.

Selection Criteria. Line C was a randomly selected control with restriction based on pedigree as described below. Line I was selected for increased index of ovulation rate and embryonal survival to $50 \mathrm{~d}$ of gestation. Selection criteria and responses in Line TS were previously reported (J ohnson et al., 1994).

In Line I selection was practiced over 10 generations for increased index followed by one generation of random selection of gilts, although sires of Generation 11 females were selected as described below. Then three generations of selection for increased number of fully formed pigs at birth (Generations 12 to 14) was practiced. The index included number of corpora lutea ( OR) and embryonal survival (ES), measured as the ratio of fetuses $(\mathbf{F})$ to $\mathrm{OR}(\mathrm{ES}=\mathrm{F} / \mathrm{OR})$ at $50 \mathrm{~d}$ of gestation. The index used from Generations 0 to 5 ( I I) was as follows: $I_{1}=10.6 \times$ OR $+72.6 \times E S$.

The index was constructed to maximize expected change in litter size at birth (J ohnson et al., 1984). Coefficients were calculated using traditional selection index methods with economic weight for each trait being the estimated population mean for the other trait (Smith, 1967). Because of the increase in OR after five generations (Neal et al., 1989), a revised index $\left(\mathbf{I}_{\mathbf{2}}\right)$ was used from Generations 6 through 11. This index was $\mathrm{I}_{2}=9.9 \times \mathrm{OR}+148.6 \times \mathrm{ES}$.

Selection Procedures. Total number of pigs born each generation, number of litters, and number of sires are presented in Table 1. All surviving Line I gilts were mated if they expressed estrus during the breeding period. Laparotomy was performed on pregnant gilts at $50 \mathrm{~d}$ of gestation to expose uteri and ovaries. Number of corpora lutea and fetuses were counted. The index was calculated and the highest-ranking gilts (45 to 55 per generation) were selected. The remainder were culled before parturition.

Two sons of each of the 15 dams with greatest index values were selected. One boar from each litter and two from the five highest-indexing dams were designated as breeders (20 in total); the remaining boars were alternates and used only if primary boars died or failed to breed.

Approximately 30 boars and 55 gilts in Line $C$ were selected. One gilt was selected randomly from every litter that had at least one gilt, and one additional gilt was selected from randomly chosen litters to make a sample of 55 gilts. Two boars were selected from each paternal half-sib family; one was designated as a breeder, the other as an alternate.

Laparotomies were not performed in Line $\mathrm{C}$ gilts that farrowed in Generation 0. The base generation mean for line I was considered to represent both lines. In Generations 5 and 10, laparotomies were performed

Table 1. Number of pigs, litters, and sires and number of gilts evaluated at each stage during each generation for index (I) and control (C) lines

\begin{tabular}{|c|c|c|c|c|c|c|c|c|c|c|c|c|c|}
\hline \multirow[b]{2}{*}{ Generation } & \multicolumn{2}{|c|}{ Pigs } & \multicolumn{2}{|c|}{ Litters } & \multicolumn{2}{|c|}{ Sires } & \multicolumn{2}{|c|}{$\begin{array}{l}\text { Gilts at } 50 \mathrm{~d} \\
\text { gestation }\end{array}$} & \multicolumn{3}{|c|}{$\begin{array}{l}\text { Gilts that } \\
\text { farrowed }\end{array}$} & \multicolumn{2}{|c|}{$\begin{array}{l}\text { Gilts with } \\
\text { weaning record }\end{array}$} \\
\hline & 1 & C & 1 & $\mathrm{C}$ & 1 & C & 1 & $\mathrm{C}$ & 1 & & a & 1 & C \\
\hline-1 & 160 & 160 & 46 & 46 & 19 & 19 & - & - & 42 & 41 & & 42 & 40 \\
\hline 0 & 432 & 391 & 42 & 41 & 15 & 15 & 128 & - & 43 & 41 & & 43 & 41 \\
\hline 1 & 472 & 426 & 43 & 41 & 20 & 14 & 127 & 23 & 43 & 20 & $(20)$ & 43 & 39 \\
\hline 2 & 466 & 362 & 43 & 40 & 18 & 15 & 131 & 24 & 44 & 21 & $(21)$ & 44 & 42 \\
\hline 3 & 460 & 389 & 44 & 42 & 17 & 16 & 148 & 23 & 44 & 21 & $(21)$ & 44 & 41 \\
\hline 4 & 464 & 350 & 44 & 42 & 19 & 15 & 150 & 21 & 44 & 22 & $(21)$ & 40 & 43 \\
\hline 5 & 472 & 384 & 44 & 43 & 19 & 15 & 122 & 43 & 48 & & (43) & 44 & 41 \\
\hline 6 & 557 & 390 & 48 & 43 & 18 & 16 & 164 & 22 & 44 & 24 & $(20)$ & 43 & 43 \\
\hline 7 & 513 & 435 & 44 & 44 & 19 & 15 & 170 & 24 & 45 & 19 & $(22)$ & 44 & 39 \\
\hline 8 & 519 & 406 & 45 & 41 & 18 & 15 & 155 & 22 & 51 & 20 & $(22)$ & 49 & 38 \\
\hline 9 & 574 & 339 & 51 & 42 & 20 & 16 & 156 & 19 & 47 & 20 & $(16)$ & 46 & 33 \\
\hline 10 & 554 & 336 & 47 & 36 & 17 & 15 & 162 & 48 & 53 & & (39) & 53 & 37 \\
\hline 11 & 667 & 371 & 53 & 39 & 20 & 15 & - & - & 60 & 47 & & 57 & 45 \\
\hline 12 & 674 & 467 & 60 & 47 & 15 & 17 & - & - & 47 & 41 & & 47 & 41 \\
\hline 13 & 648 & 400 & 47 & 41 & 14 & 16 & - & - & 79 & 47 & & 75 & 45 \\
\hline 14 & 1,049 & 412 & 79 & 47 & 15 & 16 & - & - & 97 & 43 & & 87 & 40 \\
\hline 15 & 1,302 & 416 & 97 & 43 & 18 & 14 & - & - & - & 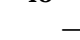 & - & - & - \\
\hline Total & 9,983 & 6,434 & 877 & 718 & 301 & 264 & 1,613 & 269 & 831 & 427 ( & (245) & 801 & 648 \\
\hline
\end{tabular}

aNumbers in parentheses are control gilts with laparotomy. 
in all Line $C$ gilts to increase numbers for estimating responses in OR and $\mathrm{F}$. Laparotomies were performed in one-half of Line $C$ gilts in other generations to estimate effects of laparotomy on fetal survival past $50 \mathrm{~d}$ of gestation and on litter size at birth.

Line I gilts in Generation 0 that farrowed were a selected sample because they ranked highest for index. Therefore, litter size data for the $F_{2}$ gilts (Generation -1) were included in analyses as base generation means to improve precision of estimating responses.

Matings were random with the exception that fulland half-sib matings were avoided. There were 36 to 43 Line $C$ litters and 42 to 53 Line I litters per generation from Generations -1 to 10 .

Index selection was terminated after 10 generations, but Line I gilts in Generation 10 that farrowed were a selected sample. A random sample of their progeny, gilts from Generation 11, were mated and farrowed to estimate selection response in litter size in unselected gilts in which laparotomy had not been performed. However, their sires were selected on the index; therefore, total index selection applied was calculated through Generation 11. There were 53 Line I litters in Generation 11.

Selection for Generations 12 to 14 in Line I was based on number of fully formed pigs in the litter in which pigs were born. Two boars, a primary breeder and an alternate, were selected from each of the 15 largest litters. Gilts from the largest litters were selected until the desired number was attained. Number of litters in Line I was increased at Generation 13. There were 47, 79, and 97 Line I litters by dams from Generations 12,13 , and 14, respectively. These dams were selected from 15, 22, and 28 litters, respectively.

Management of Pigs. Pigs were in confinement buildings throughout their lives. Neonatal pigs were transferred among litters both within and across lines within $2 \mathrm{~d}$ after birth. The objective was to give each sow between 8 and 11 pigs to nurse, which was accomplished for $73 \%$ of litters; $12 \%$ of the sows had fewer than 8 pigs after transfer, and $15 \%$ had more than 11.

Weaning was at $28 d$ of age through Generation 11 and at approximately $12 \mathrm{~d}$ of age for Generations 12 through 14. Pigs were moved to nursery rooms at weaning, where they stayed to approximately $56 \mathrm{~d}$ of age when selections were made. Selected pigs were moved to naturally ventilated buildings with 10 pigs per pen. Boars and gilts were in separate buildings.

Estrus detection in gilts began on the day the oldest pig in each pen reached $130 \mathrm{~d}$ of age. Each pen of gilts was moved daily to an adjacent building and given 15 to $20 \mathrm{~min}$ of boar exposure. Day of puberty was recorded for each gilt when it showed the immobile response to a boar.

Generation interval was $1 \mathrm{yr}$. Gilts averaged approximately $250 \mathrm{~d}$ of age when mated. The breeding period was approximately 5 to $6 \mathrm{wk}$. A gilt in first or second estrus was not mated if she would be in estrus at a later date in the breeding season. The objective was to mate gilts at their third or later estrus, although younger gilts and those that were old at puberty were mated at their second and, in a few cases, at their pubertal estrus. A total of 2,634 gilts had data at $50 \mathrm{~d}$ of gestation and(or) at farrowing. Of this total, 33 gilts were mated at their pubertal estrus and 58 at their second estrus. No adjustment for estrus number at conception was made because so few gilts were mated at their first or second estrus. Also, selections were made without regard for estrus number or age of gilt. Therefore, the analysis produces estimates of responses appropriate for the procedures used. Gilts were mated each day they were in estrus and placed in stalls for the gestation period.

Laparotomies were performed weekly. The range in day of gestation when laparotomy was performed was 47 to 54 , but $90 \%$ of the gilts were evaluated at 49,50 , or $51 \mathrm{~d}$ of gestation. No adjustment for day of gestation at time of laparotomy was made.

Gilts were kept in recovery rooms for $2 \mathrm{~d}$ after laparotomy and then returned to stalls. Feed was withheld for at least $12 \mathrm{~h}$ before laparotomy, but gilts had continuous access to water. They were given approximately $1 \mathrm{~kg}$ of feed the morning of the day after surgery and again the next day. Within 2 or $3 d$, most gilts were consuming the daily allotment of the gestation diet.

Corn-soybean meal diets were used. Percentage CP in the diets was $21 \%$ in nursery diets to pig weights of approximately $12 \mathrm{~kg}$ and $18.2 \%$ to $56 \mathrm{~d}$ of age. Diets were formulated to contain $16 \% \mathrm{CP}$ for pigs from $56 \mathrm{~d}$ of age to approximately $55 \mathrm{~kg} \mathrm{BW}$ and $14 \%$ from $55 \mathrm{~kg}$ BW to mating age. Diets fed during the gestation period had $11.5 \% \mathrm{CP}$, and diets fed during lactation had $13.2 \%$ CP. The ME in diets ranged from 3,475 $\mathrm{kcal} / \mathrm{kg}$ for nursery diets to $3,180 \mathrm{kcal} / \mathrm{kg}$ for gestation diets.

Pigs were provided ad libitum access to feed until they were approximately $180 \mathrm{~d}$ of age (gilts) or $160 \mathrm{~d}$ of age (boars). Thereafter until mating, they were given approximately $2.3 \mathrm{~kg}$ of feed per day. Gilts were given $2.1 \mathrm{~kg}$ of feed per day during the gestation period, except this amount was increased to $2.5 \mathrm{~kg}$ during the last $14 \mathrm{~d}$ of gestation. Sows had ad libitum access to feed during the lactation period.

Traits Measured. Number of corpora lutea and number of fetuses were counted at $50 \mathrm{~d}$ of gestation. Embryonal survival and index were calculated from these values. Number of fully formed pigs, number of live pigs, number of stillborn pigs, number of mummified pigs, and weight of all fully formed pigs at birth were recorded. Nurse dam for all pigs transferred to another litter was recorded. Each pig was weighed when weaned.

Traits included in the analyses were OR, F, ES, I ${ }_{1}$, $I_{2}$, total born per litter (TB), number born alive per 
litter ( NBA), number of stillborn pigs per litter ( SB), number of mummified pigs per litter (MUM), total weight of fully formed pigs at birth per litter ( LBW), number of pigs weaned ( NW), and total weight of pigs weaned by each sow ( WW). All records were considered a trait of the gilt.

Data Analyses. Data were first fitted to general linear models (SAS, 1996) to calculate the mean and standard deviation for each line-generation subclass. Models for traits at $50 \mathrm{~d}$ of gestation included line, generation, and their interaction. The effect of laparotomy treatment was added to this model for litter birth traits. The model for NW and WW included line, generation, their interaction, the linear and quadratic effects of number of pigs after crossfostering, and the linear effect of weaning age. Number weaned per litter and litter weaning weight for sows given an opportunity to nurse pigs and that subsequently lost the entire litter were recorded as 0 . Sows with all pigs fostered to other sows within $2 \mathrm{~d}$ after birth were excluded from analyses of weaning traits.

Selection differentials for indexes, ovulation rate, embryonal survival rate, and fetuses at $50 \mathrm{~d}$ of gestation for each gilt were calculated by deviating its record from the line-generation mean. Selection differentials for $I_{1}$ were calculated for gilts selected from Generations 0 through 4, and $I_{2}$ selection differentials were calculated for gilts selected from Generations 5 through 10. Cumulative selection differentials for gilts were calculated as the average cumulative selection differential of parents plus the gilt's selection differential. Cumulative selection differentials for boars were calculated by averaging the cumulative selection differentials of the boar's parents. Therefore, index cumulative selection differentials accumulate the selection applied for $I_{1}$ and $I_{2}$. Selection applied was described by calculating the average cumulative selection differential of the sires and dams of the gilts evaluated each generation and averaging these values for each line-generation subclass. Selection differentials for control gilts not evaluated at $50 \mathrm{~d}$ of gestation were set to 0 for calculation of cumulative selection differentials.

Genetic parameters and genetic responses were estimated with an animal model, using the MTDFREML programs described by Boldman et al. (1995). All known pedigree relationships back to the sample of purebreds were included. Each trait was analyzed with a single-trait model to obtain initial estimates of variance components. Models included direct animal genetic effect, common environmental effect of litter of birth, and fixed effects of generation and laparotomy treatment (included only for birth traits). Linear and quadratic covariates for number of pigs after cross-fostering and linear covariates for weaning age were included for NW and WW. Variance components due to gilt's litter of birth were less than $1 \%$ of the phenotypic variation for all traits except ovulation rate, number of fetuses, and embryonal survival rate. Litter effects were included in subse quent analyses of these traits but were deleted from models for all other traits.

Then, two- and three-trait analyses were performed to obtain initial estimates of covariance components. Final models included two, three, four, or five traits, depending on the combination of traits. The convergence criterion, the variance of the likelihood values in the simplex, in all analyses was $1.0 \times 10^{-9}$. Convergence at this value in all analyses was attained. Solutions for fixed effects and estimated breeding values were obtained when convergence was attained. Estimating responses in traits directly selected for and correlated responses in litter size traits at birth were main objectives. Because selection was for OR and ES, these traits should be included in each analysis. Convergence was attained for all three-trait models including OR, ES, and one other trait, but not for fourtrait models. Convergence was attained when OR and $F$ were fitted in four- and five-trait models. Therefore, $O R$ and $F$ were fitted in four- and five-trait models to estimate responses in TB, NBA, SB, and MUM, and in three-trait models with LBW, NW, and WW. Only 28-d litter weaning weights were included in these analyses. Combinations of traits analyzed together were as follows:

1. OR, ES, and $F$,

2. $O R, F, T B$, and NBA,

3. $\mathrm{OR}, \mathrm{F}, \mathrm{NBA}, \mathrm{SB}$, and MUM (variance/covariance components for OR, $F$, and NBA were fixed at solutions for combination 2 ),

4. OR, F, and LBW,

5. OR, F, and NW,

6. OR, $F$, and WW,

7. $I_{1}$ and $I_{2}$, and

8. $O R$ and $E S$ in three-trait models with TB, NBA, SB, MUM, LBW, NW, and WW.

The general form of the models was $\mathbf{y}=\mathbf{X} \beta+\mathbf{W}_{\tau}+$ $\mathbf{Z}_{\mu}+\mathbf{e}$, where $\mathbf{y}$ is the vector of observations for the combination of traits in a specific analysis, $\beta, \tau, \mu$, and e are vectors of fixed, litter, animal direct genetic, and residual effects, and $\mathbf{X}, \mathbf{W}$, and $\mathbf{Z}$ are known design matrices. Expectations and variances of random variables are as follows:

$$
\mathrm{E}\left[\begin{array}{c}
\boldsymbol{\tau} \\
\boldsymbol{\mu} \\
\mathbf{e}
\end{array}\right]=\left[\begin{array}{l}
\mathbf{0} \\
\mathbf{0} \\
\mathbf{0}
\end{array}\right] ; \quad \mathrm{V} \quad\left[\begin{array}{l}
\boldsymbol{\tau} \\
\boldsymbol{\mu} \\
\mathbf{e}
\end{array}\right]=\left[\begin{array}{llll}
\mathbf{D}_{0} \otimes \mathrm{I} & \mathbf{0} & \mathbf{0} \\
\mathbf{0} & \mathbf{G}_{0} \otimes \mathbf{A} & \mathbf{0} & \\
\mathbf{0} & \mathbf{0} & \mathbf{R}_{0} \otimes & \mathbf{I}
\end{array}\right],
$$

where $\otimes$ denotes a direct product operation, $\mathbf{D}_{0}, \mathbf{G}_{0}$, and $\mathbf{R}_{0}$ are common-environmental (litter of birth), additive genetic, and residual covariance matrices, with order equal to the number of traits in the analysis, $\mathbf{A}$ is the numerator relationship matrix, and I is an identity matrix of appropriate order. 
Variances, heritabilities, genetic correlations, and estimates of breeding values from the model with the greatest number of traits in which each trait was included are reported. For example, parameter estimates for OR, F, TB, and NBA are those from traits in combination 2, and those for LBW, NW, WW are from combinations 4, 5, and 6, respectively.

Responses to selection were estimated with orthogonal contrasts among the estimated breeding values $(\hat{\mu})$. Contrasts were generated in final, multiple-trait models that contained OR, F, and other traits as described above. A vector of coefficients ( $\mathbf{k}$ ) was generated and entered into MTDFREML to produce linear contrasts of the $\hat{\mu}$. The contrasts were the linear regression of $\hat{\mu}$ on generation for Line I, Line C, and Line I - Line C. Coefficients in $\mathbf{k}$ for traits at $50 \mathrm{~d}$ of gestation were obtained by dividing each respective value in the vector of orthogonal coefficients, $c^{\prime}=[-5$, $-4,-3,-2,-1,0,1,2,3,4$, and 5$]$, by the number of observations in the respective line-generation mean. Each contrast was of breeding value estimates for gilts with data at $50 \mathrm{~d}$ of gestation in Line I and gilts with either data at $50 \mathrm{~d}$ of gestation or gilts with a farrowing record in Line $\mathrm{C}$.

The vector of orthogonal coefficients for traits at birth and weaning was $c^{\prime}=-7.5,-6.5,-5.5,-4.5,-3.5$, $-2.5,-1.5,-.5, .5,1.5,2.5,3.5,4.5,5.5,6.5$, and 7.5 divided by the number of observations per linegeneration. The contrast was of estimated breeding values of Line I gilts with data at $50 \mathrm{~d}$ of gestation from Generation 0 to 10 and Line I gilts with a farrowing record for other generations, including Generation -1 . Line $C$ gilts with either $50-d$ gestation records or farrowing records were included in contrasts.

Regression coefficients were calculated as $\mathbf{k}^{\prime} \hat{\boldsymbol{\mu}} / \mathbf{c} \mathbf{c}$. The results are coefficients equal to regressions of line means on generation number. The variance of $\mathbf{k}^{\prime} \hat{\boldsymbol{\mu}}$ was calculated in MTDFREML as V $\left(\mathbf{k}^{\prime} \hat{\boldsymbol{\mu}}\right)=\mathbf{k}^{\prime} \mathbf{L}^{\mathbf{2 2}} \mathbf{k}$, where $\mathbf{L}^{\mathbf{2 2}}$ is the animal-by-animal part of the inverse of the coefficient matrix from the mixed-model equations at convergence for the variance components. Standard errors of regression coefficients were calculated from $\left[\mathrm{V}\left(\mathbf{k}^{\prime} \hat{\mu}\right)\right]^{.5} / \mathbf{c}^{\mathbf{c}} \mathbf{c}$. Significance of regressions was determined with a t-test with degrees of freedom equal to $\mathrm{g}$ 2 , equivalent to degrees of freedom in test of regression of $\mathrm{g}$ means on generation number, where $\mathrm{g}$ is the number of generations in the contrast.

Responses during each phase of the experiment were estimated with contrasts of $\hat{\mu}$. With the same procedure as described above, coefficients were generated to compare estimated breeding values of the last minus the first generation in a phase. Coefficients were weighted by $1 / n_{i j}$, where $n_{i j}$ is the number of observations (as described above) in the generationline mean. Contrasts compared Generation 5 with Generation 0, Generation 11 with Generation 5, and Generation 14 with Generation 11. Contrasts were made for both lines and for the difference between lines. Standard errors of contrasts were obtained directly from MTDFREML analyses. Significance of differences between means was determined using a ttest. Degrees of freedom were $g-2$, where $g$ is the number of generations from the first to the last one in the contrast (i.e., $4 \mathrm{df}$ for contrast of Generation 5 with Generation 0, $5 \mathrm{df}$ for contrast of Generation 11 with Generation 5, and 2 df for contrast of Generation 14 with Generation 11).

Inbreeding coefficients were calculated using MTDFREML analyses. They were averaged by linegeneration for all pigs, those with records at $50 \mathrm{~d}$ of gestation, and those with records at birth to determine whether there was a tendency to select pigs with less inbreeding than average. Phenotypic records or estimated breeding values were not adjusted for inbreeding.

\section{Results}

Phenotypic Means and Standard Deviations. Line by generation means and pooled within-generation standard deviations are given in Tables 2 through 4. Means of lines for traits at $50 \mathrm{~d}$ of gestation (Table 2) and litter traits at birth (Table 3 ) began to diverge early in the experiment and continued to diverge at a steady rate. Means in Line C were relatively stable, with most divergence caused by changes in Line I. Embryonal survival in Line I decreased with increasing ovulation rate. Greater numbers of stillborn and mummified pigs at birth in Line I accompanied the increases in ovulation rate, number of fetuses, and number of pigs per litter. Line differences in number of mummified pigs were greatest during the period of index selection. Some of this difference was due to the laparotomy procedure, because Line $\mathrm{C}$ gilts with laparotomy averaged $.44 \pm .12$ more mummified pigs than gilts without laparotomy. Laparotomy in Line C gilts also reduced number of fully formed pigs (.97 \pm .26) and number born alive (.81 \pm .26$)$. Laparotomy did not significantly affect number of stillborn pigs. Laparotomy caused fetal mortality even beyond losses documented by mummies because number of fetuses was less than the sum of total born plus mummies.

Mean number weaned was similar for Lines I and C in early generations, but Line $C$ consistently weaned more pigs from Generations 6 to 14. Mean litter weaning weight was similar for both lines throughout the experiment (Table 4).

With the exception of ovulation rate, standard deviations were similar for both lines. Standard deviations of ovulation rate in Line I ranged from 2.6 to 3.6 during Generations 0 to 5, and from 4.4 to 8.8 during Generations 6 to 10. Standard deviations of ovulation rate in Line $C$ ranged from 2.0 to 4.2. Pooled within-generation standard deviations of ovulation 
Table 2. Means and standard deviations for traits measured at $50 \mathrm{~d}$ of gestation

\begin{tabular}{|c|c|c|c|c|c|c|c|c|}
\hline \multirow[b]{2}{*}{ Generation } & \multicolumn{2}{|c|}{$\begin{array}{c}\text { Number of corpora lutea } \\
(\mathrm{OR})\end{array}$} & \multicolumn{2}{|c|}{$\begin{array}{c}\text { Number of fetuses } \\
(\mathrm{F})\end{array}$} & \multicolumn{2}{|c|}{$\begin{array}{c}\text { Embryonal survival rate } \\
(E S=F / O R)\end{array}$} & \multicolumn{2}{|c|}{ Index points } \\
\hline & Line I & Line C & Line I & Line C & Line I & Line $C$ & Line I & Line $C$ \\
\hline 0 & 13.98 & - & 10.81 & - & .79 & - & $205.7^{\mathrm{a}}$ & - \\
\hline 1 & 14.31 & 13.04 & 11.15 & 9.57 & .79 & .74 & $209.4^{\mathrm{a}}$ & $192.3^{a}$ \\
\hline 2 & 15.11 & 14.32 & 10.85 & 10.96 & .73 & .78 & $212.8^{a}$ & $208.6^{a}$ \\
\hline 3 & 15.76 & 14.35 & 11.56 & 10.48 & .74 & .74 & $220.7^{\mathrm{a}}$ & $205.3^{a}$ \\
\hline 4 & 15.95 & 13.24 & 11.49 & 9.52 & .73 & .73 & $221.9^{a}$ & $193.1^{\mathrm{a}}$ \\
\hline 5 & 17.02 & 14.02 & 11.89 & 10.91 & .71 & .78 & $\begin{array}{l}231.7^{\mathrm{a}} \\
274.0^{\mathrm{b}}\end{array}$ & $\begin{array}{l}205.3^{a} \\
255.1^{b}\end{array}$ \\
\hline 6 & 17.98 & 13.09 & 12.70 & 9.91 & .73 & .84 & $286.2^{\mathrm{b}}$ & $255.4^{b}$ \\
\hline 7 & 18.87 & 14.46 & 13.03 & 11.29 & .73 & .79 & $295.0^{b}$ & $260.3^{b}$ \\
\hline 8 & 21.23 & 14.41 & 13.08 & 9.73 & .67 & .69 & $310.3^{b}$ & $245.1^{\mathrm{b}}$ \\
\hline 9 & 20.70 & 13.00 & 12.99 & 10.00 & .67 & .79 & $304.4^{b}$ & $245.9^{b}$ \\
\hline 10 & 20.46 & 13.77 & 13.64 & 10.33 & .72 & .76 & $309.4^{b}$ & $250.0^{\mathrm{b}}$ \\
\hline$\sigma^{c}$ & 5.44 & 2.63 & 2.87 & 2.70 & .18 & .22 & $\begin{array}{l}29.4^{\mathrm{a}} \\
(55.3)^{\mathrm{b}}\end{array}$ & $\begin{array}{l}24.9^{\mathrm{a}} \\
(34.7)^{\mathrm{b}}\end{array}$ \\
\hline
\end{tabular}

$\mathrm{a}_{1}=10.6 \times \mathrm{OR}+72.6 \times \mathrm{ES}$, selection criterion for Generations 1 through 5 .

$\mathrm{b}_{2}=9.9 \times \mathrm{OR}+148.6 \times \mathrm{ES}$, selection criterion for Generations 6 through 10 .

cPooled within-generation standard deviation.

rate were 5.44 in Line I and 2.63 in Line C (Table 2). The increase in variation in ovulation rate in Line I was caused by an increase in the incidence of gilts with very high ovulation rates. During Generations 0 to 5, seven gilts had more than 24 corpora lutea; the maximum value was 44 . Number of gilts with more than 24 corpora lutea from Generations 6 to 10 was 7, $11,24,16$, and 24, respectively. Maximum counts within generation ranged from 48 to 79 corpora lutea, and means for these gilts with $O R>24$ ranged from 33.1 in Generation 6 to 37.7 in Generation 9. Only two Line $\mathrm{C}$ gilts had more than 24 corpora lutea; each had 28 corpora lutea.

The increased variation in OR increased variation in indexes as the experiment progressed but did not affect variation in number of fetuses or embryonal survival rate (Table 2). Within-generation standard deviations of number of fetuses ranged from 2.5 to 3.3

Table 3. Means and standard deviations for litter traits at birth

\begin{tabular}{|c|c|c|c|c|c|c|c|c|c|c|c|c|c|c|c|}
\hline \multirow[b]{2}{*}{ Generation } & \multicolumn{3}{|c|}{$\begin{array}{l}\text { Number of fully } \\
\text { formed pigs per litter }\end{array}$} & \multicolumn{3}{|c|}{$\begin{array}{c}\text { Number of live pigs } \\
\text { per litter }\end{array}$} & \multicolumn{3}{|c|}{$\begin{array}{l}\text { Number of stillborn } \\
\text { pigs per litter }\end{array}$} & \multicolumn{3}{|c|}{$\begin{array}{l}\text { Number of } \\
\text { mummified pigs } \\
\text { per litter }\end{array}$} & \multicolumn{3}{|c|}{$\begin{array}{l}\text { Total litter birth } \\
\text { weight, } \mathrm{kg}\end{array}$} \\
\hline & Line I & $\begin{array}{l}\text { Line } \\
\text { C, } \\
\text { lap }\end{array}$ & $\begin{array}{c}\text { Line } \\
\text { C, } \\
\text { no lap }\end{array}$ & Line I & $\begin{array}{l}\text { Line } \\
\text { C, } \\
\text { lap }\end{array}$ & $\begin{array}{l}\text { Line } \\
\text { C, } \\
\text { no lap }\end{array}$ & Line I & $\begin{array}{l}\text { Line } \\
\text { C, } \\
\text { lap }\end{array}$ & $\begin{array}{l}\text { Line } \\
\text { C, } \\
\text { no lap }\end{array}$ & Line I & $\begin{array}{l}\text { Line } \\
\text { C, } \\
\text { lap }\end{array}$ & $\begin{array}{l}\text { Line } \\
\text { C, } \\
\text { no lap }\end{array}$ & Line I & $\begin{array}{l}\text { Line } \\
\text { C, } \\
\text { lap }\end{array}$ & $\begin{array}{l}\text { Line } \\
\text { C, } \\
\text { no lap }\end{array}$ \\
\hline-1 & 10.29 & - & 9.54 & 9.86 & - & 9.32 & .43 & - & .22 & .17 & - & .05 & 13.5 & - & 13.0 \\
\hline 0 & 10.98 & - & 10.39 & 10.49 & - & 10.20 & .49 & - & .20 & .56 & - & .24 & 14.0 & - & 13.1 \\
\hline 1 & 10.84 & 8.45 & 9.65 & 10.28 & 8.20 & 9.40 & .56 & .25 & .25 & .95 & .35 & .40 & 12.9 & 10.8 & 11.1 \\
\hline 2 & 10.45 & 9.05 & 9.48 & 9.70 & 8.48 & 9.24 & .75 & .57 & .24 & 1.34 & 1.05 & .29 & 12.3 & 11.0 & 11.7 \\
\hline 3 & 10.55 & 8.00 & 8.67 & 9.32 & 7.71 & 8.29 & 1.23 & .29 & .38 & 1.86 & 1.29 & 1.05 & 11.9 & 9.6 & 10.8 \\
\hline 4 & 10.73 & 7.71 & 10.09 & 8.98 & 7.52 & 9.68 & 1.75 & .19 & .41 & 1.20 & .62 & .59 & 12.5 & 10.0 & 12.4 \\
\hline 5 & 11.60 & 9.23 & - & 9.81 & 8.23 & - & 1.79 & 1.00 & - & 1.56 & 1.21 & - & 12.5 & 11.1 & - \\
\hline 6 & 11.70 & 9.20 & 10.46 & 10.14 & 8.55 & 9.71 & 1.57 & .65 & .75 & 2.57 & .45 & .17 & 13.4 & 12.5 & 14.1 \\
\hline 7 & 11.60 & 9.32 & 10.63 & 10.40 & 8.77 & 9.58 & 1.20 & .55 & 1.05 & 1.76 & 1.05 & .21 & 11.9 & 11.6 & 13.4 \\
\hline 8 & 11.25 & 7.59 & 8.60 & 9.22 & 7.14 & 8.00 & 2.04 & .45 & .60 & 1.65 & .55 & .45 & 11.4 & 9.5 & 11.0 \\
\hline 9 & 11.79 & 9.25 & 9.40 & 10.17 & 8.69 & 8.45 & 1.62 & .56 & .95 & 1.55 & .31 & .10 & 11.3 & 11.5 & 11.2 \\
\hline 10 & 12.58 & 9.51 & - & 10.72 & 9.15 & - & 1.87 & .36 & - & 1.19 & .36 & - & 12.1 & 10.9 & - \\
\hline 11 & 11.23 & - & 9.94 & 9.58 & - & 9.21 & 1.65 & - & .72 & .70 & - & .17 & 12.0 & - & 11.4 \\
\hline 12 & 13.79 & - & 9.76 & 11.49 & - & 8.95 & 2.30 & - & .80 & .60 & - & .46 & 14.3 & - & 11.4 \\
\hline 13 & 13.28 & - & 8.77 & 10.38 & - & 8.47 & 2.90 & - & .30 & .49 & - & .17 & 13.7 & - & 10.6 \\
\hline 14 & 13.42 & - & 9.67 & 11.37 & - & 9.30 & 2.05 & - & .37 & .47 & - & .30 & 13.5 & - & 11.2 \\
\hline$\sigma^{\mathrm{b}}$ & 2.98 & 2.47 & 2.66 & 3.02 & 2.63 & 2.57 & 2.00 & 1.08 & .94 & 1.44 & 1.27 & .80 & 3.38 & 3.07 & 3.01 \\
\hline
\end{tabular}

a Lap = laparotomy at $50 \mathrm{~d}$ of gestation, Line I had laparotomy in all gilts for Generations 0 through 10.

bpooled within-generation-treatment standard deviation. 
Table 4. Average number weaned (NW) and total weight weaned (WW), adjusted for number of pigs given sows to nurse and weaning age, by generation ${ }^{a}$

\begin{tabular}{cccccc}
\hline \hline & \multicolumn{2}{c}{ Adjusted NW } & & \multicolumn{2}{c}{ Adjusted WW, kg } \\
\cline { 2 - 3 } \cline { 5 - 6 } Generation $^{\mathrm{b}}$ & Line I & Line C & & Line I & Line C \\
\hline-1 & 8.21 & 8.42 & & 56.7 & 60.0 \\
0 & 9.38 & 9.24 & & 60.0 & 58.4 \\
1 & 8.07 & 7.64 & & 50.5 & 49.3 \\
2 & 8.19 & 8.29 & & 53.5 & 54.3 \\
3 & 7.83 & 8.40 & & 52.6 & 56.5 \\
4 & 8.24 & 8.24 & & 52.8 & 52.2 \\
5 & 8.33 & 8.28 & & 54.4 & 52.0 \\
6 & 8.55 & 8.75 & & 52.5 & 55.0 \\
7 & 8.38 & 9.00 & & 49.3 & 54.5 \\
8 & 7.92 & 8.55 & & 50.0 & 54.4 \\
9 & 8.10 & 8.53 & & 47.1 & 51.5 \\
10 & 8.51 & 8.91 & & 47.8 & 52.6 \\
11 & 8.11 & 8.29 & & 50.0 & 48.7 \\
12 & 8.34 & 9.04 & & 23.3 & 26.0 \\
13 & 8.30 & 9.20 & & 25.2 & 27.5 \\
14 & 8.62 & 9.62 & & 26.4 & 30.0 \\
$\sigma^{c}$ & 1.29 & 1.25 & & 9.7 & 9.8 \\
\hline
\end{tabular}

${ }^{a}$ Adjusted for linear and quadratic effects on number of pigs a dam was given to nurse $(\mathrm{NN})$ and linear effects of weaning age $(A)$ by generation with these equations ( $\mathrm{i}=$ line, $\mathrm{j}=$ generation): 1 ) Adjusted $(\mathrm{NW})=$ actual NW $+1.93 \times\left(\mu_{\mathrm{NNi}} \cdot-\mathrm{NN}_{\mathrm{ij}}\right)-.0705 \times$ $\left(\mu_{N N}{ }^{2} \cdot-N^{2}{ }_{i j}\right)-.0034 \times\left(27.6-A_{i j}\right)$, for Generations -1 through 11; linear and quadratic regressions on NN were 1.64 and -.048 , respectively, for Generations 12 through 14. 2) Adjusted weaning weight $(\mathrm{WW})=$ actual $\mathrm{WW}+12.46 \times\left(\mu_{\mathrm{NNi}} \cdot-\mathrm{NN}_{\mathrm{ij}}\right)-.49 \times\left(\mu_{\mathrm{NN}}{ }_{\mathrm{i}} \cdot-\right.$ $\left.N N^{2}{ }_{i j}\right)+1.304 \times\left(27.6-A_{i j}\right)$, for Generations -1 through 11 ; linear and quadratic regressions were 4.86 and -.153 for Generations 12 through 14, respectively.

bMean numbers nursed by generation were: $9.76,10.4,9.66,9.27$, $8.94,9.48,9.27,9.88,10.14,9.12,9.44,10.02,9.61,10.21,10.15$, and 10.91 for Generations -1 through 14, respectively. Mean weaning age was $27.6 \mathrm{~d}$ for Generations -1 through 11 and $12.0 \mathrm{~d}$ for Generations 12 through 14 , respectively.

'Pooled within-generation-line standard deviation.

in Line I and from 2.0 to 3.1 in Line C. Withingeneration standard deviations of embryonal survival ranged from .16 to .20 in Line I and .16 to .45 in Line $C$. The large value in Line $C$ in one generation was due mostly to one gilt with four observable corpora lutea but with 11 fetuses. A total of 20 gilts had more fetuses than distinguishable corpora lutea. In all cases, except for the one large discrepancy noted, there were either one or two more fetuses than corpora lutea.

Standard deviations of litter size at birth in Line I tended to increase as the experiment progressed. The pooled within-generation standard deviation of total born per litter was 2.8, 3.3, and 3.5 during Generations 0 to 5,6 to 10, and 11 to 14, respectively. It was 2.98 across generations. The standard deviation in Line $C$ was 2.6 and was slightly greater in gilts without laparotomy (Table 3).

Standard deviations of other traits were similar across lines with the exception that standard deviation of number of mummified pigs tended to be greater for the Line I and Line C gilts with laparotomy than for Line C gilts without laparotomy.

Inbreeding. Inbreeding coefficients of gilts that farrowed averaged .12 in Line I at Generation 10 and .17 at Generation 14 (Table 5). The range at Generation 14 was from .13 to .27 . Coefficients were .09 in Line $C$ at Generation 10 and .11 at Generation 14. Inbreeding coefficients for all pigs, those with laparotomy at $50 \mathrm{~d}$ of gestation and those selected to farrow, differed by less than $1 \%$ within generation. There was no apparent selection of gilts with lower than average inbreeding coefficients.

Selection Applied. The cumulative sel ection differential for index in Line I was 96.6 points at Generation 5 and 263.9 points at Generation 11 (Table 6). The cumulative selection differential at Generation 5 was 9.0 corpora lutea, 6.9 fetuses, and .02 for embryonal survival rate. Selection differentials were greater from Generations 6 to 11, accumulating to 25.2 corpora lutea, 15.6 fetuses, and .06 for embryonal survival rate. Selection differentials for ovulation rate were negative but were positive for fetuses, embryonal survival rate, and indexes in Line $C$.

Genetic Parameters. The REML estimates of phenotypic variances and heritabilities are given in Table 7. Heritabilities presented are from multiple-trait models, but estimates were quite consistent regardless of the number of traits in the model. For example, heritability of ovulation rate was .24 when estimated with a four-trait model including number of fetuses, total number born, and number born alive per litter. The estimate was .25 when ovulation rate was analyzed alone and .23 when ovulation rate, number of fetuses, and embryonal survival rate were analyzed together. Heritability estimates for embryonal survival rate varied most depending on the number of traits in the analysis. The estimate was .11 in a single-trait analysis, .06 when included with ovulation rate, and .14 when included with ovulation rate and number of fetuses at $50 \mathrm{~d}$ of gestation. Estimates of heritability of embryonal survival ranged from .07 to .09 when included with ovulation rate and either total born, number born alive, litter birth weight, number weaned, or litter weaning weight. Heritability estimates of other traits were similar from single-trait and multiple-trait models.

There was considerable genetic variation for all traits, including number of stillborn and mummified pigs per litter. The range in heritability estimates was from .08 for number weaned per litter to .32 for litter birth weight. Common litter environmental effects accounted for $6 \%$ of the phenotypic variation in OR, $1 \%$ of the variation in number of fetuses and embryonal survival rate, and less than $1 \%$ of the variation for all other traits.

The estimated genetic correlation between OR and embryonal survival rate was -.86 (Table 8 ). Genetic correlations of OR with number of fetuses, fully 
Table 5. Mean, minimum (Min), and maximum (Max) inbreeding by line and generation

\begin{tabular}{|c|c|c|c|c|c|c|c|c|c|c|c|c|c|c|c|}
\hline \multirow[b]{3}{*}{ Generation } & \multicolumn{9}{|c|}{ Line I } & \multicolumn{6}{|c|}{ Line $\mathrm{C}$} \\
\hline & \multicolumn{3}{|c|}{ All pigs } & \multicolumn{3}{|c|}{$\begin{array}{l}\text { Gilts at } 50 \mathrm{~d} \\
\text { gestation }\end{array}$} & \multicolumn{3}{|c|}{ Gilts that farrowed } & \multicolumn{3}{|c|}{ All pigs } & \multicolumn{3}{|c|}{ Gilts that farrowed } \\
\hline & Mean & Min & $\operatorname{Max}$ & Mean & Min & $\operatorname{Max}$ & Mean & Min & $\operatorname{Max}$ & Mean & Min & Max & Mean & Min & $\operatorname{Max}$ \\
\hline-1 & & & & & & & & & & .003 & 0 & .031 & & & \\
\hline 0 & .017 & 0 & .070 & .016 & 0 & .070 & .014 & 0 & .063 & .015 & 0 & .063 & .016 & 0 & .063 \\
\hline 1 & .020 & 0 & .092 & .018 & 0 & .092 & .020 & .004 & .080 & .022 & 0 & .074 & .022 & .004 & .074 \\
\hline 2 & .037 & .011 & .134 & .041 & .011 & .134 & .039 & .011 & .086 & .035 & .008 & .095 & .035 & .008 & .095 \\
\hline 3 & .058 & .017 & .105 & .059 & .017 & .102 & .056 & .017 & .091 & .034 & .010 & .084 & .035 & .010 & .083 \\
\hline 4 & .067 & .029 & .153 & .068 & .029 & .153 & .067 & .036 & .153 & .038 & .021 & .096 & .038 & .021 & .096 \\
\hline 5 & .063 & .037 & .148 & .059 & .039 & .148 & .062 & .039 & .148 & .054 & .022 & .100 & .054 & .022 & .100 \\
\hline 6 & .082 & .045 & .173 & .082 & .045 & .173 & .083 & .045 & .173 & .064 & .037 & .277 & .059 & .037 & 107 \\
\hline 7 & .091 & .022 & .189 & .093 & .022 & .189 & .097 & .065 & .153 & .066 & .046 & .116 & .064 & .046 & .116 \\
\hline 8 & .104 & .036. & .198 & .103 & .036. & 198 & .106 & .054 & .172 & .081 & .056 & .129 & .083 & .056 & .129 \\
\hline 9 & .112 & .076. & .200 & .110 & .076 & .200 & .106 & .076. & .200 & .079 & .022 & .163 & .080 & .022 & .163 \\
\hline 10 & .120 & .089. & .237 & .118 & .089 & .237 & .119 & .089. & .237 & .084 & .045 & .150 & .088 & .045 & .150 \\
\hline 11 & .135 & 109 & .233 & - & - & - & .140 & 109 & .233 & . 096. & .064 & .172 & .096 & .064 & .172 \\
\hline 12 & .144 & .106. & .235 & - & - & - & .139 & .120. & .157 & .098. & .026 & .148 & .098 & . 078 & 148 \\
\hline 13 & .152 & .127. & .205 & - & - & - & .152 & .127. & .194 & . 102 & .028 & .153 & .100 & . 028. & 153 \\
\hline 14 & .164 & . 077. & .266 & - & - & - & .169 & 132 & .266 & .111. & .062 & .153 & .112 & .062 & 153 \\
\hline 15 & .182 & 147. & .260 & - & - & - & - & - & - & 119 & .090 & .170 & - & - & - \\
\hline
\end{tabular}

formed, stillborn, and mummified pigs were between .24 and .44. Ovulation rate was not correlated with number born alive and was negatively correlated with number weaned and litter weaning weight. Number of fetuses at $50 \mathrm{~d}$ of gestation had a positive genetic correlation with all traits except number weaned. Number of fetuses was most highly correlated with number of fully formed pigs but was also highly correlated with number of live and stillborn pigs. Embryonal survival was most highly correlated with number of fetuses and number per litter at birth, but it was not correlated with number of stillborn and mummified pigs. Phenotypic correlations of OR and number of fetuses with other traits were somewhat less than genetic correlations, whereas phenotypic correlations of embryonal survival with other traits were similar to genetic correlations.

Regressions on Generations. Regressions of estimated breeding values on generation number are given in Table 9. Line $\mathrm{C}$ regressions were not significant for any trait, whereas all Line I regressions were significant, except number of mummified pigs per litter $(P<.1)$ and total weaning weight $(P>.1)$. All responses in Line I expressed as a deviation from Line $C$ were significant $(P<.05)$ except number of mummified pigs per litter, litter birth weight, and total weaning weight.

Estimated breeding values for indexes in Line I relative to Line $C$ increased linearly at the rate of 6.2 \pm 1.0 (Index 1 ) and $5.1 \pm .8$ (Index 2) points per generation. This increase comprised an increase of .67 \pm .12 corpora lutea and a decrease of $-.008 \pm .003$ for

Table 6. Realized cumulative selection differentials for traits measured at $50 \mathrm{~d}$ of gestation

\begin{tabular}{|c|c|c|c|c|c|c|c|c|}
\hline \multirow[b]{2}{*}{ Generation } & \multicolumn{4}{|c|}{ Line I } & \multicolumn{4}{|c|}{ Line $C$} \\
\hline & Index ${ }^{a}$ & $\begin{array}{l}\text { Ovulation } \\
\text { rate }\end{array}$ & $\begin{array}{l}\text { No. of } \\
\text { fetuses }\end{array}$ & $\begin{array}{l}\text { Embryonal } \\
\text { survival rate }\end{array}$ & Index ${ }^{a}$ & $\begin{array}{l}\text { Ovulation } \\
\text { rate }\end{array}$ & $\begin{array}{l}\text { No. of } \\
\text { fetuses }\end{array}$ & $\begin{array}{l}\text { Embryonal } \\
\text { survival rate }\end{array}$ \\
\hline 1 & $12.71^{a}$ & 1.10 & 1.13 & .01 & 0 & 0 & 0 & 0 \\
\hline 2 & $32.21^{a}$ & 2.95 & 2.46 & .01 & -1.47 & -.20 & -.01 & .01 \\
\hline 3 & $50.31^{a}$ & 4.85 & 3.31 & -.01 & -.46 & -.12 & .08 & .01 \\
\hline 4 & $70.61^{a}$ & 6.57 & 5.15 & .01 & -.82 & -.10 & -.05 & .00 \\
\hline 5 & $96.61^{a}$ & 8.98 & 6.87 & .02 & .70 & -.06 & .18 & .02 \\
\hline 6 & $114.28^{b}$ & 10.43 & 7.80 & .02 & -1.17 & -.09 & .08 & .01 \\
\hline 7 & $133.95^{\mathrm{b}}$ & 11.97 & 9.73 & .06 & 3.97 & -.32 & .47 & .06 \\
\hline 8 & $154.64^{b}$ & 13.70 & 11.54 & .09 & 4.14 & -.35 & .47 & .07 \\
\hline 9 & $185.87^{\mathrm{b}}$ & 16.94 & 13.20 & .08 & 3.58 & -.21 & .77 & .06 \\
\hline 10 & $225.32^{\mathrm{b}}$ & 21.44 & 14.50 & .05 & 8.22 & .31 & 1.06 & .05 \\
\hline 11 & $263.89^{a}$ & 25.19 & 15.55 & .06 & 6.01 & -.32 & .82 & .08 \\
\hline
\end{tabular}

alndex 1.

bIndex 2, summed to Index 1 values. 
Table 7. REML estimates of phenotypic variances $\left(\sigma_{\mathrm{p}}^{2}\right)$, heritabilities $\left(h^{2}\right)$, proportions of variance due to litter of birth $\left(c^{2}\right)$, and residual variances $\sigma_{\mathrm{e}}^{2}$ using data from all available pigs

\begin{tabular}{lcccc}
\hline \hline Trait & $\sigma_{\mathrm{p}}^{2}$ & $\mathrm{~h}^{2}$ & $\mathrm{c}^{2}$ & $\sigma_{\mathrm{e}}^{2}$ \\
\hline Index 1 & $2,470.2$ & .20 & 0 & $1,968.1$ \\
Index 2 & $2,059.5$ & .16 & 0 & $1,726.0$ \\
Ovulation rate & 27.5 & .24 & .06 & 19.0 \\
Embryonal survival rate & .036 & .14 & .01 & .03 \\
Number of fetuses at d 50 & 8.43 & .18 & .01 & 6.87 \\
Total number born per litter & 8.64 & .16 & 0 & 7.26 \\
Number born alive per litter & 8.26 & .17 & 0 & 6.89 \\
Number of stillborn pigs per litter & 3.03 & .17 & 0 & 2.52 \\
Number of mummified pigs per litter & 1.74 & .12 & 0 & 1.53 \\
Total litter birth weight, kg & 10.58 & .32 & 0 & 7.24 \\
Number weaned per litter & 1.77 & .08 & 0 & 1.62 \\
Litter 28-d weaning weight, kg & 96.9 & .25 & 0 & 72.7 \\
\hline
\end{tabular}

embryonal survival rate (Figure 1). Number of fetuses increased at a rate of $.35 \pm .06$ per generation. Changes in the indexes and component traits tended to be greater from Generations 5 to 11 than from Generations 0 to 5 (Table 10).

Estimated breeding values during the 14 generations of selection increased in Line I relative to Line C at a rate of $.21 \pm .04$ fully formed pigs per generation. This increase was composed approximately equally of an increase of $.10 \pm .04$ live pigs and $.12 \pm .03$ still born pigs (Figures 2 and 3 ). Response in litter birth weight was not significant because average birth weight of pigs declined as number of pigs increased in Line I.

Response in fully formed pigs for Line I was estimated to be $.75 \pm .31$ pigs during Generations 0 to $5,1.37 \pm .34$ pigs during Generations 5 to 11 , and 1.21 \pm .34 pigs from Generations 11 to 14 (Table 10). Responses in number born alive were $.25 \pm .32$ and .58 \pm .35 pigs during selection for Index 1 and Index 2 , respectively, whereas the response was $.99 \pm .34$ pigs during Generations 12 to 14 when direct selection for litter size was practiced. Estimated breeding value for number of stillborn pigs increased $.40 \pm .19$ pigs from Generations 0 to 5, and number of mummified pigs increased by $.38 \pm .14$ pigs. The increase in number of stillborn pigs from selection for Index $2(.81 \pm .21)$ was greater than the increase from selection for Index 1 , but the increase in number of mummified pigs was less $(.16 \pm .15)$. During Generations 12 to 14 , estimated breeding value for stillborns in Line I relative to Line $C$ increased $.47 \pm .20$ pigs, but number of mummified pigs declined -.19 \pm .14 pigs.

The average response in breeding value for number weaned was $-.046 \pm .015$ pigs per generation (Table $9)$, which was negative, but not significant $(P>.10)$, during each phase of the experiment (Table 10, Figure $4)$. Neither regression on generation nor change in total weaning weight during each phase was significant.

Table 8. REML estimates of correlations among ovulation rate, number of fetuses at $50 \mathrm{~d}$ of gestation, and embryonal survival rate, and between these traits and other traits using data from all available pigs

\begin{tabular}{|c|c|c|c|c|c|c|}
\hline \multirow[b]{2}{*}{ Trait $^{a}$} & \multicolumn{3}{|c|}{ Genetic correlations } & \multicolumn{3}{|c|}{ Phenotypic correlations } \\
\hline & OR & $\mathrm{F}$ & ES & OR & $\mathrm{F}$ & ES \\
\hline $\mathrm{F}$ & .44 & - & .47 & .17 & - & .67 \\
\hline ES & -.86 & - & - & -.47 & - & - \\
\hline TB & .24 & .85 & .36 & .03 & .63 & .48 \\
\hline NBA & -.02 & 61 & .36 & 0 & .49 & .37 \\
\hline SB & .34 & .67 & -.01 & .06 & .33 & .15 \\
\hline MUM & .27 & .17 & 0 & .07 & .24 & .09 \\
\hline LBW & -.10 & .47 & .24 & -.10 & .42 & .38 \\
\hline NW & -.37 & -.18 & .07 & -.10 & -.01 & .07 \\
\hline WW & -.18 & .12 & .16 & -.08 & -.09 & -.04 \\
\hline
\end{tabular}

${ }^{\mathrm{a} O R}=$ ovulation rate (corpora lutea) at $50 \mathrm{~d}, \mathrm{~F}=$ number of fetuses at $50 \mathrm{~d}, \mathrm{ES}=\mathrm{F} / \mathrm{OR}, \mathrm{TB}=$ total number of pigs per litter, NBA = number of live pigs per litter, SB = number of stillborn pigs per litter, MUM = number of mummified pigs per litter, LBW = total litter birth weight, NW = adjusted number of pigs weaned per litter, and $W W=28-d$ adjusted litter weaning weight. 
Table 9. Coefficients (b) and SE for regression of mean estimated breeding values on generation by trait and line

\begin{tabular}{|c|c|c|c|c|c|c|}
\hline \multirow[b]{2}{*}{ Trait $^{a}$} & \multicolumn{2}{|c|}{ Line I } & \multicolumn{2}{|c|}{ Line $C$} & \multicolumn{2}{|c|}{$I-C$} \\
\hline & b & se & b & se & b & se \\
\hline OR & $.583 * *$ & .082 & -.090 & .082 & $.673^{* *}$ & .116 \\
\hline $\mathrm{F}$ & $.295^{* *}$ & .039 & -.053 & .038 & $.348^{* *}$ & .055 \\
\hline ES & $-.005^{*}$ & .002 & .003 & .002 & $-.008^{*}$ & .003 \\
\hline$I_{1}$ & $4.879 * *$ & .723 & -1.279 & .722 & $6.158 * *$ & 1.022 \\
\hline $\mathrm{I}_{2}$ & $4.012^{* *}$ & .589 & -1.044 & .586 & $5.056 * *$ & .831 \\
\hline TB & $.216 * *$ & .031 & .004 & .030 & $.212^{* *}$ & .043 \\
\hline NBA & $.123 * *$ & .031 & .020 & .030 & $.103^{*}$ & .043 \\
\hline SB & $.111 * *$ & .019 & -.004 & .018 & $.115^{* *}$ & .026 \\
\hline MUM & $.023^{\dagger}$ & .013 & -.006 & .012 & .029 & .018 \\
\hline LBW & $.143^{* *}$ & .045 & .058 & .045 & .058 & .064 \\
\hline NW & $-.037^{* *}$ & .011 & .009 & .010 & $-.046 * *$ & .015 \\
\hline WW & -.088 & .141 & .093 & .129 & -.181 & .191 \\
\hline
\end{tabular}

${ }^{\mathrm{a} O R}=$ ovulation rate; $\mathrm{F}=$ number of fetuses; $\mathrm{ES}=$ embryonal survival rate; $\mathrm{I}_{1}=$ index $1 ; \mathrm{I}_{2}=$ index 2 ; $\mathrm{TB}=$ total born per litter; $\mathrm{NBA}=$ number born alive; $\mathrm{SB}=$ number of stillborn pigs; $\mathrm{MUM}=$ number of mummified pigs; LBW = litter birth weight, NW = number weaned; WW = litter weaning weight, $\mathrm{kg}$. ${ }^{\dagger} \mathrm{p}<.10$.

$* P<.05$.

$* * \mathrm{P}<.01$.

\section{Discussion}

When this experiment began, several studies with mice had been successful for improving litter size with direct selection (see reviews in Bakker et al., 1976 and J oakimsen and Baker, 1977). Reports of only one similar selection experiment in pigs were available (Ollivier and Bolet, 1981; Ollivier, 1982). Results in pigs were not the same as those in mice. Little change occurred after 11 generations of selection in pigs (Bolet et al., 1989). Other studies found that selection for ovulation rate was successful in mice and pigs, but

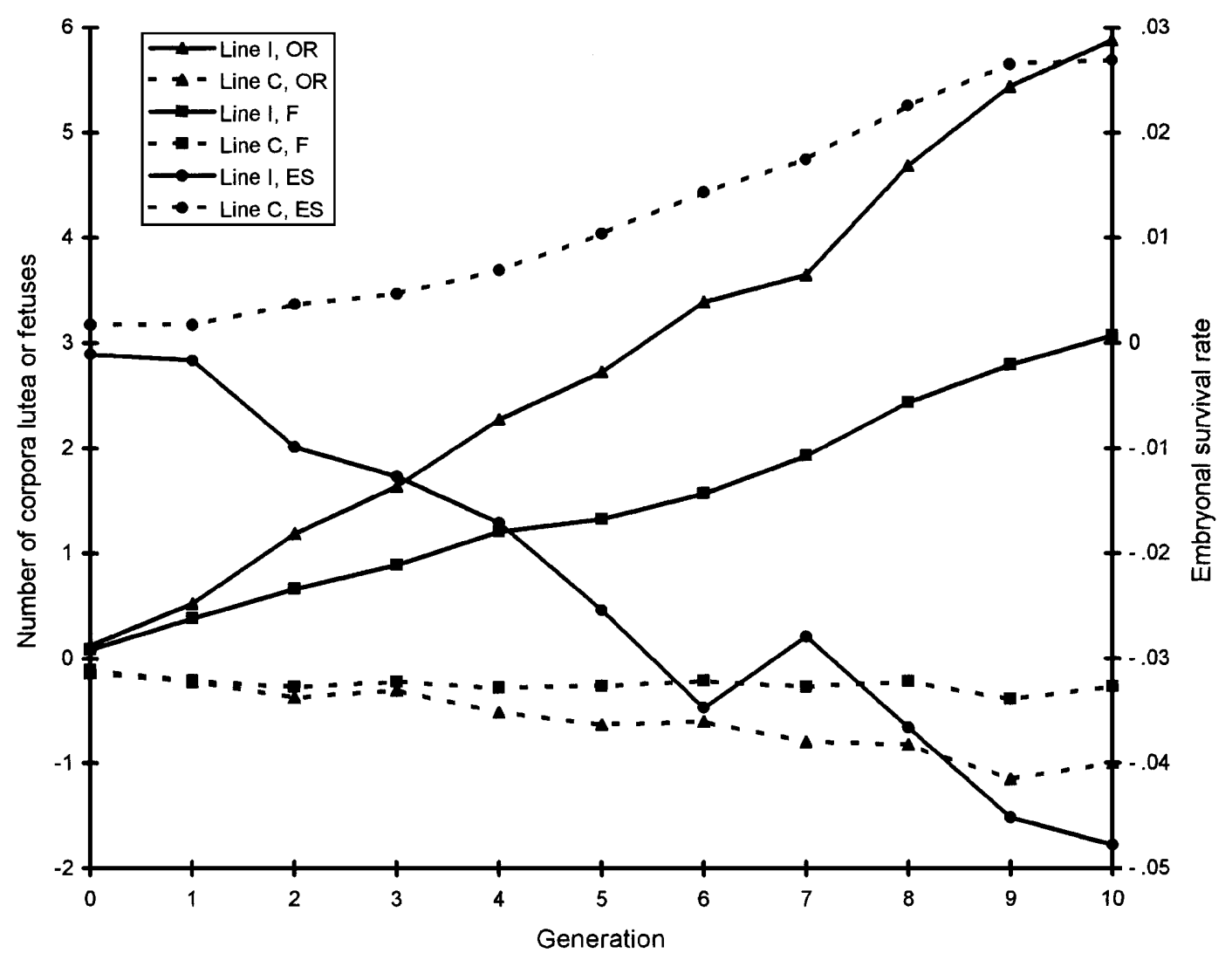

Figure 1. Mean estimated breeding values for ovulation rate (OR), fetuses at $50 \mathrm{~d}$ of gestation (F), and embryonal survival rate (ES) for index (I) and control (C) lines. 
increases in litter size relative to ovulation rate were small (Bradford, 1979; Cunningham et al., 1979). However, Bradford (1969) demonstrated genetic variation in prenatal survival in mice. He selected for increased ovulation rate in one line and increased prenatal survival, the ratio of normal fetuses in late gestation to ovulation rate (the ratio weighted by number of fetuses), in another line. Improvement in component traits in each line occurred, but significant increase in litter size occurred only in the line selected for prenatal survival.

Results of the experiments in mice and pigs led us to initiate index selection for OR and embryonal survival. The index was designed to maximize response in litter size (J ohnson et al., 1984). It was constructed based on results of selection for increased OR in the Nebraska Gene Pool population (Zimmer- man and Cunningham, 1975; Cunningham et al., 1979). Responses were predicted for a population of the same size using the same selection method as in the experiment reported herein.

Predicted response was .29 pigs per generation, with responses in component traits of .78 oocytes and -.019 for embryonal survival rate. The observed response based on estimated breeding values over 11 generations in Line I as a deviation from Line $C$ in number of fetuses at $50 \mathrm{~d}$ gestation $(.348 \pm .055$ fetuses) was greater than predicted. However, the response per generation in estimated breeding values in Line I was .295 \pm .039 fetuses, almost exactly equal to predicted response. Agreement between observed and predicted response in litter size was reasonably close, even though observed response in OR (.673 \pm .116 oocytes) and embryonal survival rate $(-.008 \pm$

Table 10. Contrasts between generation mean EBV for pairs of generations

\begin{tabular}{|c|c|c|c|c|c|c|}
\hline Trait $^{a}$ & Line I & SE & Line $\mathrm{C}$ & SE & $\mathrm{I}-\mathrm{C}$ & SE \\
\hline & \multicolumn{6}{|c|}{ Generation 5 minus Generation 0} \\
\hline OR & $2.602^{*}$ & .618 & -.352 & .65 & $2.954^{*}$ & .671 \\
\hline $\mathrm{F}$ & $1.244 * *$ & .029 & .001 & .03 & $1.23^{*}$ & .317 \\
\hline ES & -.02 & .017 & .013 & .018 & -.037 & .019 \\
\hline $\mathrm{I}_{1}$ & $22.78^{*}$ & 5.45 & -5.56 & 5.73 & $28.34 * *$ & 6.02 \\
\hline $\mathrm{I}_{2}$ & $18.62 *$ & 4.43 & -4.51 & 4.64 & $23.12 * *$ & 4.93 \\
\hline TB & $.876^{*}$ & .289 & .128 & .294 & $.748^{\dagger}$ & .308 \\
\hline NBA & 0.439 & .296 & .194 & .3 & .245 & .319 \\
\hline SB & $.416^{\dagger}$ & .179 & .143 & .18 & .402 & .192 \\
\hline MUM & .23 & .122 & -.147 & .121 & $.377^{*}$ & .135 \\
\hline LBW & .499 & .434 & .436 & .439 & .063 & .438 \\
\hline NW & -.13 & .105 & .026 & .103 & -.157 & .12 \\
\hline \multirow[t]{2}{*}{ WW } & .189 & 1.221 & .298 & 1.221 & -.119 & 1.279 \\
\hline & \multicolumn{6}{|c|}{ Generation 11 minus Generation 5} \\
\hline OR & $4.013 * *$ & .71 & -.567 & .695 & $4.58 * *$ & .831 \\
\hline $\mathrm{F}$ & $1.971 * *$ & .326 & -.119 & .321 & $2.09 * *$ & .361 \\
\hline ES & -.04 & .02 & .012 & .02 & -.048 & .024 \\
\hline $\mathrm{I}_{1}$ & $30.81^{* *}$ & 6.34 & -6.17 & 6.21 & 36.98* & 7.75 \\
\hline $\mathrm{I}_{2}$ & $25.41 * *$ & 5.16 & -5.08 & 5.03 & $30.49 * *$ & 6.32 \\
\hline TB & $1.408 * *$ & .316 & .035 & .318 & $1.373^{*} *$ & .34 \\
\hline NBA & $.729^{\dagger}$ & .325 & .145 & .311 & .584 & .35 \\
\hline SB & $.802 * *$ & .196 & -.007 & .187 & $.809 *$ & .21 \\
\hline MUM & .168 & .135 & .011 & .126 & .157 & .149 \\
\hline LBW & .553 & .469 & .364 & .456 & .188 & .458 \\
\hline NW & $-.27^{\dagger}$ & .118 & .063 & .108 & -.33 & .135 \\
\hline \multirow[t]{2}{*}{ WW } & -1.38 & 1.363 & .474 & 1.289 & -1.855 & 1.452 \\
\hline & \multicolumn{6}{|c|}{ Generation 14 minus Generation 11} \\
\hline OR & 1.291 & .72 & -.154 & .594 & 1.445 & .905 \\
\hline $\mathrm{F}$ & $1.063^{\dagger}$ & .308 & -.162 & .266 & 1.225 & .372 \\
\hline TB & $1.08^{\dagger}$ & .285 & -.132 & .252 & 1.211 & .338 \\
\hline NBA & $.9^{\dagger}$ & .285 & -.009 & .251 & .993 & .337 \\
\hline SB & .382 & .172 & -.09 & .152 & .473 & .202 \\
\hline MUM & -.11 & .117 & .082 & .101 & -.193 & .14 \\
\hline LBW & $1.489^{\dagger}$ & .399 & -.135 & .366 & 1.623 & .442 \\
\hline NW & -.11 & .103 & .031 & .087 & -.142 & .127 \\
\hline
\end{tabular}

${ }^{\mathrm{a} O R}=$ ovulation rate; $F=$ number of fetuses; $E S=$ embryonal survival rate; $I_{1}=$ index $1 ; I_{2}=$ index 2 ; $\mathrm{TB}=$ total born per litter; NBA = number born alive; $\mathrm{SB}=$ number of stillborn pigs; $\mathrm{MUM}=$ number of mummified pigs; LBW = litter birth weight, kg; NW = number weaned; WW = litter weaning weight, $\mathrm{kg}$. ${ }^{\dagger} \mathrm{P}<.10$.

$* \mathrm{P}<.05$.

$* * P<.01$. 


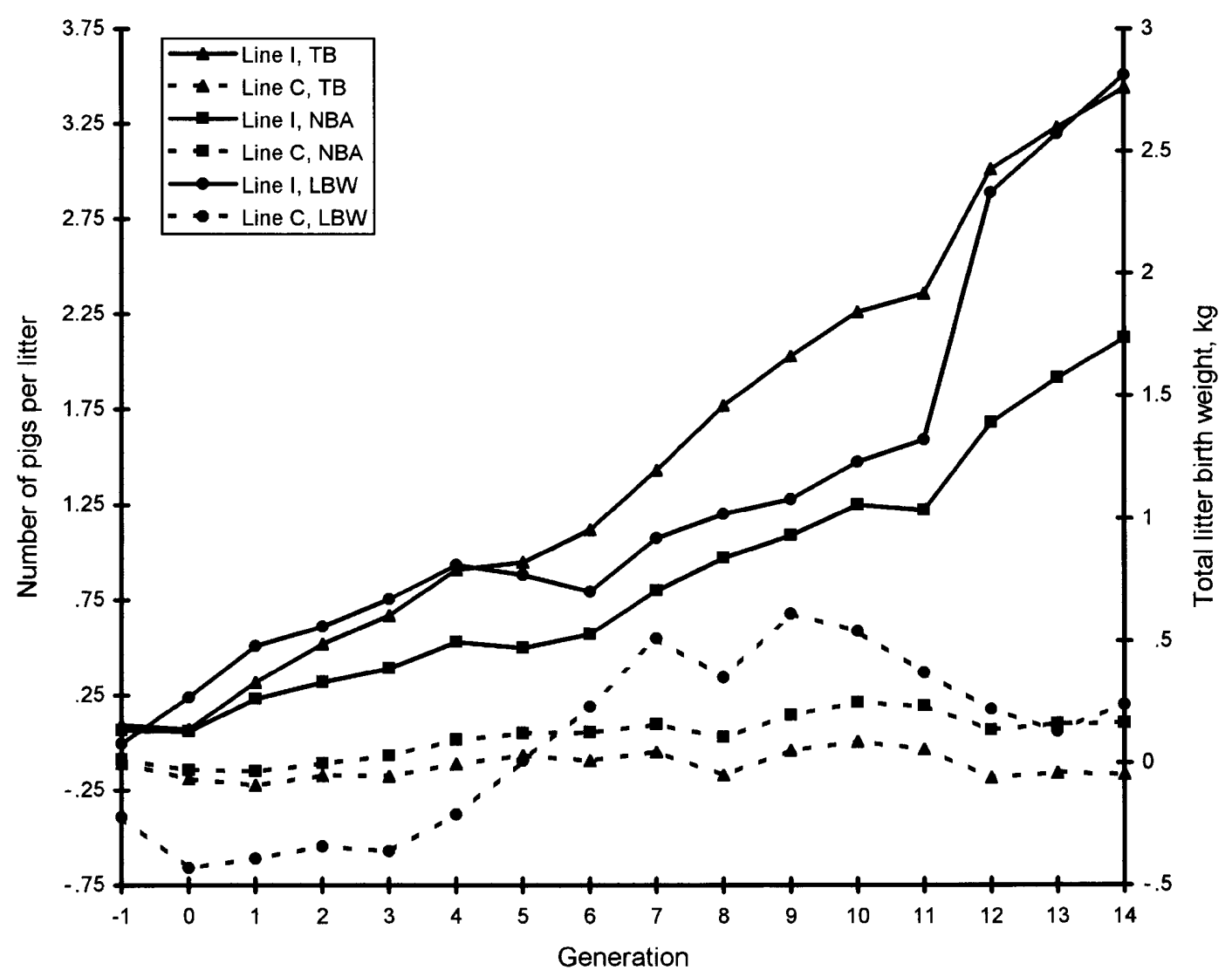

Figure 2. Mean estimated breeding values for number of fully formed pigs (TB), number born alive (NBA), and litter birth weight (LBW) for index (I) and control (C) lines.

.003 ) were $86 \%$ and $42 \%$, respectively, of predicted values.

Observed response in total born per litter $(.212 \pm$ .043 pigs, deviated from Line $C$, or $.216 \pm .031$ pigs, directly in Line I) was less than the predicted response because the estimated genetic correlation between number of fetuses at $50 \mathrm{~d}$ of gestation and total number born was .85. J ohnson et al. (1984) assumed this value to be close to one based on data available indicating that most prenatal death had occurred by $50 \mathrm{~d}$ of gestation. However, Christenson et al. (1987) used unilateral hysterectomy-ovariectomy to increase number of fetuses in one uterine horn and found significant fetal death late in gestation. Increased fetal deaths after $50 \mathrm{~d}$ of gestation with selection for Index 1 was evident at Generation 5 because Line I had .377 \pm .135 more mummified pigs than Line C (Table 10). Number of mummified pigs continued to increase, although not significantly, with selection for Index 2 and then declined during Generations 11 to 14 with direct selection for litter size. The decline in number of mummified pigs during direct selection for litter size was not significant but is in agreement with Gama and J ohnson (1993), who found that approximately $25 \%$ of the increase in litter size with selection for litter size in a line previously selected for increased OR was explained by a reduction in number of mummified pigs.
The selection index was modified at Generation 5 because optimum weights on component traits depend on means (J ohnson et al., 1984). Ovulation rate increased and embryonal survival decreased during the first five generations (Neal et al., 1989). Greater response from the updated selection index was predicted. Responses per generation in all traits at 50 $\mathrm{d}$ of gestation and birth, except number of mummified pigs per litter, as measured by differences in mean breeding value between last and first generation, were greater during Generations 6 to 11 than Generations 1 to 5 . The differences were not significant but ranged from an $8 \%$ greater rate of decrease in embryonal survival to a $99 \%$ increase in number born alive. Changing the index most probably had little effect on realized responses. The REML estimate of the genetic correlation between Index 1 and Index 2 was .99. Thus, the indexes were essentially the same trait genetically. Greater responses with selection for Index 2 can be attributed to larger selection differentials, due mainly to an increase in variation of ovulation rate.

Comparison of realized response in litter size using index selection with response using direct selection for litter size was not possible because it would require a contemporary line selected for litter size. However, because the index was expected to cause greater 
response, comparisons with predicted responses using parameter estimates obtained in this experiment are useful. The average number of gilts per generation with data at $50 \mathrm{~d}$ of gestation was 146.6. The average fractions selected for dams of selected males and females was .104 and .32, respectively, which correspond to standardized selection differentials of approximately 1.73 and 1.11 . Predicted response in number of fetuses applying parameter estimates $\left(\mathrm{h}^{2}=\right.$ $.18, \mathrm{SD}=2.81$ ) is .36 fetuses per generation, compared to an observed response of .35 fetuses. Mean number of litters at birth in Line I was 44.8. Predicted response in litter size at birth, assuming the same parameters as for number of fetuses and fraction selected of $33.4 \%$ for dams of both males and females, is .28 pigs per generation. Use of laparotomy at $50 \mathrm{~d}$ of gestation increased expected response by $29 \%$ due to greater selection differential for sires (3.2 times as many gilts as farrowing spaces were evaluated at $50 \mathrm{~d}$ of gestation). Predicted response in total born per litter with selection of replacements from 15 of 45 litters (standardized selection differential $=1.065, \mathrm{~h}^{2}$ $=.16$, SD $=2.94$ ) is .25 pigs per generation, compared to the observed response of .216 pigs per generation.

These calculations led to the conclusion that response in litter size in this experiment was approximately equal to what was expected with direct selection for litter size. The only experiment that has compared index selection for OR and prenatal survival (pups born/ovulation rate) with direct selection for litter size has been with mice. Although the difference was not significant, response in number born at Generation 13 was greater in the index line (Gion et al., 1990), and the increase was similar to the $25 \%$ increase over direct selection for number born predicted from base generation parameters (Clutter et al., 1990). However, response after 21 generations was greater in the line directly selected for litter size; again, the line differences were not significant (Kochera Kirby and Nielsen, 1993). The authors postulated that less response occurred in the index line because the index constructed with base generation means was not changed during the experiment and, therefore, was not optimum during later generations. However, results of that experiment and the current one seem to indicate little difference in realized response in litter size between index selection and direct selection.

Although it is useful to make comparisons between the index selection experiment in mice and our experiment, it is difficult to precisely interpret the results regarding the relative merits of index selection to increase litter size. We measured traits to $50 \mathrm{~d}$ of gestation and did not have a contemporary line selected for litter size. The experiment with mice had an appropriate design, but means changed due to

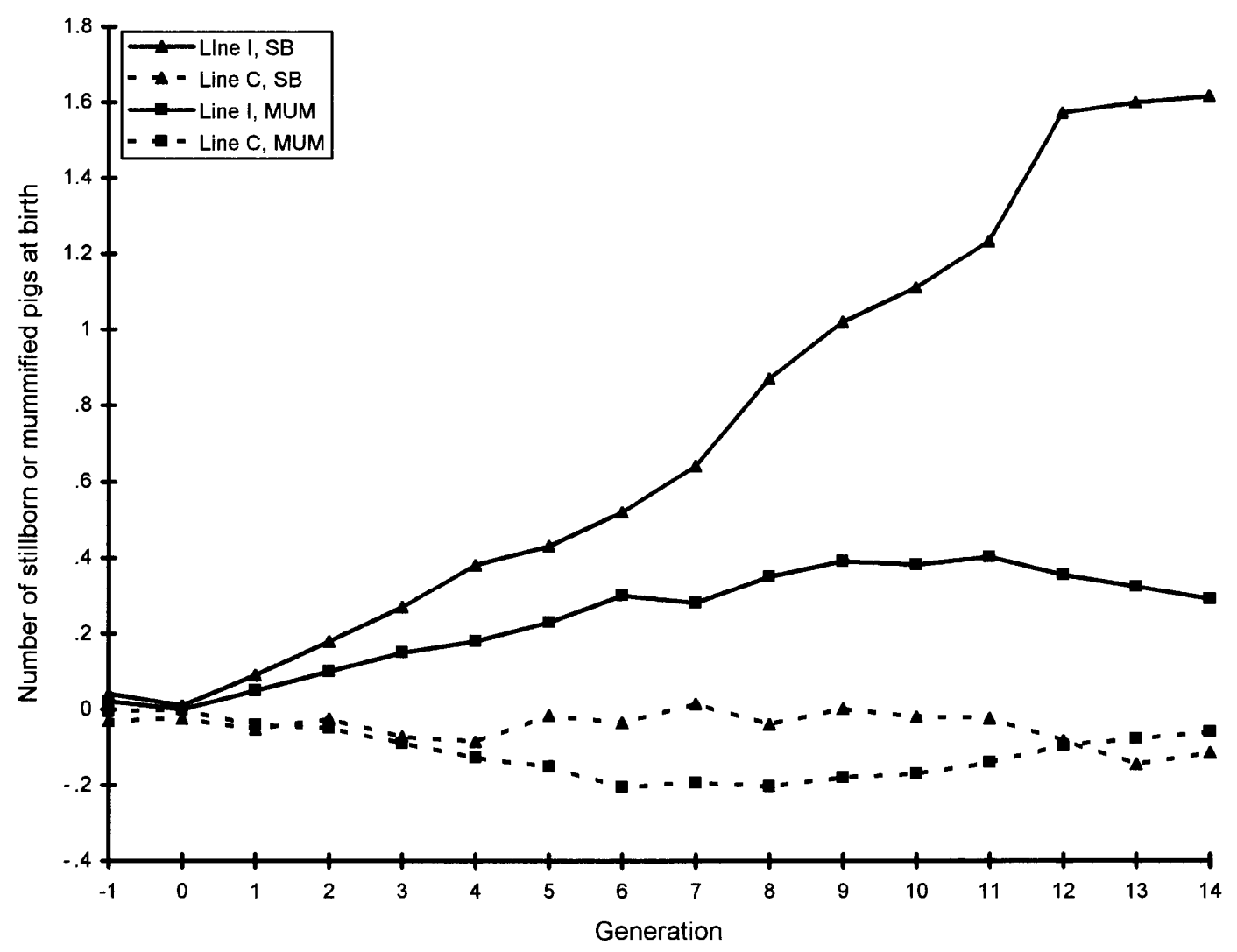

Figure 3. Mean estimated breeding values for number of stillborn (SB) and number of mummified (MUM) pigs for index (I) and control (C) lines. 


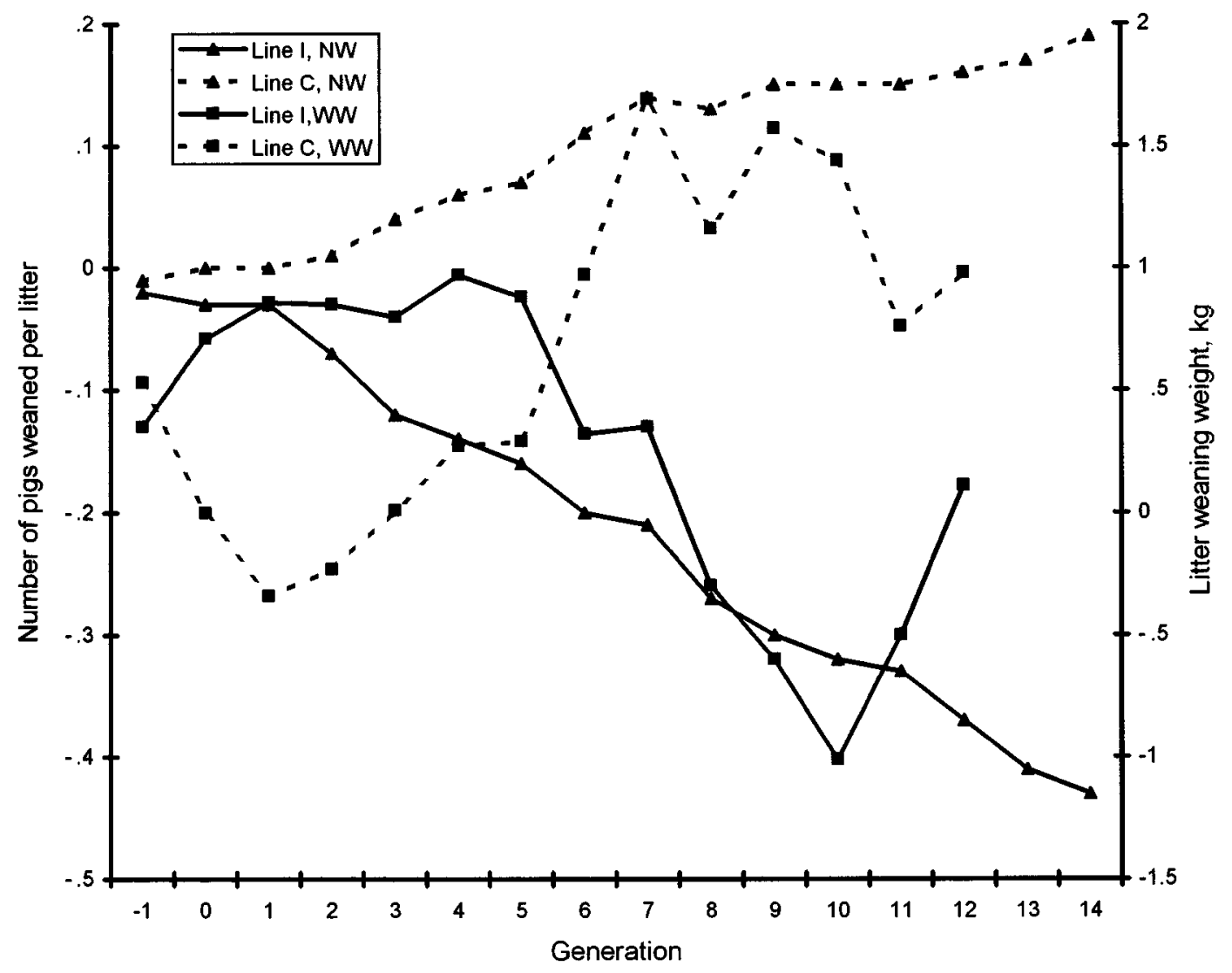

Figure 4. Mean estimated breeding values for number weaned (NW) and total 28-d weaning weight (WW) for index (I) and control (C) lines.

selection and the index was not adjusted accordingly. The experimental evidence is not sufficient to completely discard the theory on which this experiment was based.

Perez-Enciso and Bidanel (1997) gave a possible explanation for similar response between index and litter size selection. They developed formulas for relative selection weight ( $\mathrm{W}$ ) on prenatal survival (PS $=\mathrm{LS} / \mathrm{OR}$ ) and ovulation rate (OR) when litter size (LS) is the goal with index selection and direct selection. The relative weight for index selection is as follows:

$$
\begin{aligned}
& \mathrm{W}_{\mathrm{PS}} / \mathrm{W}_{\mathrm{OR}}=\left(\begin{array}{lll}
\sigma_{\mathrm{OR}, \mathrm{PS}} & \left.\sigma_{\mathrm{gOR}, \mathrm{LS}}-\sigma^{2} \mathrm{OR} \sigma_{\mathrm{gPS}, \mathrm{LS}}\right)
\end{array}\right. \\
& \div\left(\sigma_{\mathrm{OR}, \mathrm{PS}} \sigma_{\mathrm{gPS}, \mathrm{LS}}-\sigma^{2} \mathrm{PS} \sigma_{\mathrm{OR}, \mathrm{LS}}\right) \text {, }
\end{aligned}
$$

where the subscript $g$ denotes a genetic covariance; all other covariances and variances are phenotypic. The relative weight when selection is for LS is $\mu_{\mathrm{OR}} / \mu \mathrm{PS}$. Substituting ES for PS, as measured in this experiment, the calculated relative weight for index selection, assuming no change in parameters, was 23.0 during the first 11 generations, whereas relative weights from LS selection in Generations 0,5 , and 11 derived from least squares estimates of base generation means and predicted responses in component traits were calculated to be 19.3, 26.6, and 35.0. Relative to direct selection, the index placed similar weight on component traits and those expected from direct selection. However, direct selection for litter size during Generations 11 to 14 placed increased weight on PS, presumably due to the large response in OR during index selection.

Bennett and Leymaster (1989) described a model for litter size based on OR, potential embryonal viability, and uterine capacity ( UC). Uterine capacity was assumed to be the maximum number of fetuses a dam can carry to term. Their equations relating means and standard deviations of litter size and prenatal survival to mean OR and UC with estimated responses in Line I were used to predict changes in UC. The mean OR for the base generation was taken to be the unweighted average for Line I in Generation 0 plus all generations of Line $C$ data (13.79 ova). Base mean for total born was the average of Line I in Generation -1 and all generations of Line $C$ data for gilts without laparotomy (9.69 pigs). Prenatal survival was calculated to be the ratio of mean total born to mean OR. Line I means for different generations were calculated as base generation means plus the estimated change in breeding values in Line I during each phase.

Based on these calculations, UC was 10.05 pigs in the base population. It increased to 10.5 pigs with 
Table 11. Predicted means and standard deviations by generation in Line I for ovulation rate (OR), total born (TB), uterine capacity (UC), and prenatal survival (PS) using equations of Bennett and Leymaster (1989)

\begin{tabular}{|c|c|c|c|c|c|c|c|c|}
\hline \multirow[b]{2}{*}{ Generation } & \multicolumn{4}{|c|}{ Means } & \multicolumn{4}{|c|}{ Standard deviations } \\
\hline & OR & TB & UC & PS & OR & $\mathrm{TB}^{\mathrm{a}}$ & UC & PS \\
\hline Base & 13.79 & 9.69 & 10.05 & .67 & $2.63^{b}$ & $2.71(2.66)$ & 3.53 & .19 \\
\hline 5 & 16.39 & 10.57 & 10.50 & .62 & - & $3.06(2.21)$ & 3.69 & .185 \\
\hline 11 & 20.40 & 11.98 & 11.75 & .59 & - & $3.65(3.10)$ & 4.12 & .194 \\
\hline 14 & 21.69 & 13.06 & 13.10 & .61 & - & $4.00(3.53)$ & 4.60 & .206 \\
\hline
\end{tabular}

avalues in parentheses are observed standard deviations.

bObserved standard deviation of OR in the base generation; the equations did not predict standard deviation for OR.

selection for Index 1 (Table 11). Then, as the index placed more emphasis on embryonal survival with increased OR, predicted UC increased to 11.75 pigs at Generation 11 and 13.1 pigs at Generation 14. The model predicted an increase in the standard deviation of total born with selection. The observed standard deviation of litter size was $97 \%$ of that predicted in the base population and increased with selection but in later generations was only 72 to $83 \%$ of the predicted standard deviation. The model predicted standard deviations of UC that ranged from 3.53 to 4.6, values similar to that of 4.2 pigs assumed by Bennett and Leymaster (1989). Response in total born in Line I (3.37 pigs by this method) was predicted to be due jointly to increases in OR and UC, approximately 7.9 oocytes and three pigs, respectively.

These calculations indicate that genetic variation in UC was at least partially expressed in the measure of embryonal survival at $50 \mathrm{~d}$ gestation. Because number of mummified pigs increased with index selection, embryonal survival to $50 \mathrm{~d}$ of gestation did not measure full expression of UC. No procedure was found to calculate a correlation between embryonal survival at d 50 with UC. However, the observed genetic correlation between number of fetuses and total born indicates a strong, but less than perfect, association.

Reliable estimates of mean OR and UC are needed to predict responses in litter size and prenatal survival with the OR - UC model (Bennett and Leymaster, 1990a,b). When means of OR and UC are unbalanced, litter size selection places most emphasis on the limiting trait. Responses in component traits depend on whether OR and UC are in balance or whether mean OR is high, similar, or low relative to UC. Based on their definition of balance (OR - UC $=.68$ ), the base population used in this experiment was out of balance $(O R-U C=3.74)$ and became more unbalanced with index selection as OR exceeded UC by 8.7 at Generation 11 .

Bennett and Leymaster (1990b) predicted 13\% greater response from selection on an index of OR and UC than from an index of OR and embryonal survival and $27 \%$ greater response than from direct selection for litter size. Using results of selection in mice for an index of OR and prenatal survival, or selection for either UC or litter size, Ribeiro et al. (1997) predicted responses for various selection criteria. In close agreement with predicted responses in pigs, litter size response from selection for an index of OR and UC was approximately $10 \%$ greater than from index of OR and prenatal survival and $24 \%$ greater than direct selection. Based on the work in mice and pigs, greater response from selection on index of OR and UC than from the indexes used in this experiment is predicted, but a very large experiment is needed to determine that realized differences or lack of differences are not due to genetic drift (Perez-Enciso and Bidanel, 1997).

The incidence of gilts with extreme numbers of corpora lutea in this experiment caused variance of OR to be greater than values found in other experiments. For example, phenotypic standard deviations of 2.6 oocytes (J ohnson et al., 1984) and 2.4 oocytes (Haley and Lee, 1992) are typical of literature values, compared with the REML estimate of 5.2 for this experiment. Even though the heritability estimate of OR was .24, compared to a realized heritability of .46 (Cunningham et al., 1979) and the REML estimate of .31 found by Haley and Lee (1992), genetic variance was approximately twice that found in other experiments.

The incidence of gilts with extreme OR may have contributed to the large, negative correlations of OR with embryonal survival $\left(r_{g}=-.86, r_{p}=-.47\right)$. Phenotypic correlations in pigs of -.42 (J ohnson et al., 1984) and -.32 (Christenson et al., 1987) have been reported. The simulated phenotypic correlation by Bennett and Leymaster (1989) was -.22 with simulated genetic correlations of -.40 and -.36 for heritability of UC of .15 and .20, respectively. Genetic correlations of -.75 (J ohnson et al., 1984) and -.56 (Neal et al., 1989) have been reported.

This experiment provides strong evidence that embryonal survival has a genetic component and that it is positively correlated with litter size. In a smaller data set with British Large White pigs, Haley and Lee 
(1992) found much different results. Heritability of prenatal survival was zero and thus their estimated genetic correlation of OR with litter size was close to unity. We found both OR $\left(r_{g}=.24\right)$ and embryonal survival $\left(r_{g}=.36\right)$ to be correlated with total born per litter. Heritability of prenatal survival in mice estimated from simulated data was .06 (Ribeiro et al., 1997). Bennett and Leymaster (1989) estimated values of .08 and .11 in simulated data. Bolet et al. (1994) reported estimates of genetic correlations in rabbits of .11 to .18 between embryonal and total prenatal survival.

Estimates of heritability of litter size in pigs are approximately .10 (Haley et al., 1988). Estimates found here, .16 for total born and .17 for number of pigs born alive, were considerably greater. Number of stillborn and mummified pigs per litter also had genetic components with heritabilities of .17 and .13, respectively. Unfortunately, both traits were positively correlated with components of litter size. Number of stillborn pigs especially increased with selection for increased total number born. As a result, only approximately $50 \%$ of the increase in total born was in live pigs. Comparable relationships in the literature between OR and number of fetuses with stillborn and mummified pigs were not found. The undesirable correlated response in number of stillborn pigs indicates that the measurement of UC or prenatal survival should be based on number of live pigs at birth.

Greater genetic variation in litter size traits may be due to the selection response in OR. As OR increased, UC increasingly became the limiting variable for litter size. Measures of litter size then became measures of effects of UC on fetal survival rate, especially of those effects in late gestation. The indexes used did not exploit genetic variation for effects of UC on fetal mortality after $50 \mathrm{~d}$ of gestation. Selecting on component traits of litter size probably would have been more effective if $O R$ and prenatal survival or a measure of UC to term had been used.

Two important findings in this study are the correlated responses in Line I of increased number of stillborn pigs and decreased number weaned. Increased incidence of stillborn pigs seems partly related to birth weight. Averaged over generations, birth weight of live pigs averaged $1.12 \mathrm{~kg}$ in Line I and 1.24 $\mathrm{kg}$ in Line $C(P<.01)$. Average birth weight of stillborn pigs was significantly less than weight of live pigs in both Lines I and C (.23 and .19 kg, respectively). This difference in birth weight between live and stillborn pigs remained consistent throughout the experiment. Average birth weight tended to decline in Line I with selection for larger litters. Although not significant, response in total birth weight was very similar to response in total born per litter (F igure 2). There were more small pigs in Line I and more of them were stillborn. This result is consistent with negative genetic and phenotypic correlations between litter size and birth weight in pigs (Young et al., 1977, 1978). However, van Engelen et al. (1995) did not find correlated decreases in mean pup weight in mice with selection for three criteria, index of ovulation rate and ova success, litter size, or uterine capacity, all of which caused an increase in litter size. Phenotypic regressions for individual pup weight and within-litter standard deviation of pup weight on number born were small but negative and significant. Other factors, such as time from beginning to end of parturition, which may be longer in large litters, also may be involved in the increase in number of stillborn pigs.

Decreased weight of live pigs might have contributed to greater preweaning mortality in Line I. Although cross-fostering was practiced, Line I sows frequently nursed only Line I pigs, because more often than not pigs were transferred from Line I sows to sows of another line. If birth weight was related to viability, more deaths of Line I pigs were expected. Survival rate from birth to weaning was analyzed including the genetic effect of the pig and of its nurse dam. Direct heritability, that due to genes of the pig, was $3 \%$, whereas maternal heritability, that due to genes of the nurse dam, was $7 \%$. The trends in breeding values in Line I were not significant but were negative for both direct and maternal effects. The combination of decreased genetic value for both direct and maternal effects on pig survival caused the significant negative trend in number weaned. Selection did not significantly affect maternal effect on milk production as measured by litter weaning weight.

Inbreeding increased in both lines during the experiment, but the increase was greater in Line I. Mean inbreeding in Generation 14 was .18 (range from .15 to .26) in Line I and .12 (range from .09 to .17) in Line C. Increased inbreeding of both dam and pig are known to decrease pig viability. Therefore, the decrease in pig survival to weaning and decrease in number weaned in Line I were likely related to both decreased birth weight and to increased inbreeding.

\section{Implications}

Litter size and its component traits, ovulation rate and embryonal survival, are heritable and will respond to selection. Response in litter size from selection on an index of ovulation rate and embryonal survival (or prenatal survival) is expected to be approximately equal to that from direct selection for litter size. Because number of mummified and stillborn pigs increased with increased litter size, selection criteria to increase litter size should include number and, perhaps, weight of live pigs. 


\section{Literature Cited}

Bakker, H., J. H. Wallinga, and R. D. Politiek. 1976. Reproduction and body weight of mice after long term selection for litter size. In: Proc. 27th Annu. Mtg. EAAP, Zurich, Switzerland.

Bennett, G. L., and K. A. Leymaster. 1989. Integration of ovulation rate, potential embryonic viability and uterine capacity into a model of litter size in swine. J. Anim. Sci. 67:1230-1241.

Bennett, G. L., and K. A. Leymaster. 1990a. Genetic implications of a simulation model of litter size in swine based on ovulation rate, potential embryonic viability and uterine capacity: I. Genetic theory. J. Anim. Sci. 68:969-979.

Bennett, G. L., and K. A. Leymaster. 1990b. Genetic implications of a simulation model of litter size in swine based on ovulation rate, potential embryonic viability and uterine capacity: II. Simulated selection. J. Anim. Sci. 68:980-986.

Boldman, K. G., L. A. Kriese, L. D. Van Vleck, C. P. Van Tassell, and S. D. Kachman. 1995. A manual for use of MTDFREML. A set of programs to obtain estimates of variances and covariances [draft]. ARS, USDA, Washington, DC.

Bolet, G., L. Ollivier, and P. Dando. 1989. Sélection sur la prolificité chez le porc. I. Résultats d'une expérience de sélection sur onze générations. Genet. Sel. Evol. 21:93-106.

Bolet, G., M. A. Santacreu, M. J . Argente, A. Climent, and A. Blasco. 1994. Divergent selection for uterine efficiency in unilaterally ovariectomized rabbits. I. Phenotypic and genetic parameters. Proc. 5th World Congr. Genet. Appl. Livest. Prod. 19:261.

Bradford, G. E. 1969. Genetic control of ovulation rate and embryonal survival in mice. I. Response to selection. Genetics 61: 905-921.

Bradford, G. E. 1979. Genetic variation in prenatal survival and litter size. J. Anim. Sci. 49(Suppl. 2)66-74.

Christenson, R. K., K. A. Leymaster, and L. D. Young. 1987. J ustification of unilateral hysterectomy-ovariectomy as a model to evaluate uterine capacity in swine. J. Anim. Sci. 65:738-744.

Clutter, A. C., M. K. Nielsen, and R. K. J ohnson. 1990. Alternative methods of selection for litter size in mice: I. Characterization of base population and development of methods. J. Anim. Sci. 68:3536-3542.

Cunningham, P. J ., M. E. England, L. D. Young, and D. R. Zimmerman. 1979. Selection for ovulation rate in swine: Correlated response in litter size and weight. J. Anim. Sci. 48:509-516.

Gama, L.L.T., and R. K. J ohnson. 1993. Changes in ovulation rate, uterine capacity, uterine dimensions, and parity effects with selection for litter size in swine. J. Anim. Sci. 71:608-617.

Gion, J. M., A. C. Clutter, and M. K. Nielsen. 1990. Alternative methods of selection for litter size in mice: II. Response to thirteen generations of selection. J. Anim. Sci. 68:3543-3556.

Haley, C. S., E. Avalos, and C. Smith. 1988. Selection for litter size in the pig. Anim. Breed. Abstr. 56:317-332.

Haley, C. S., and G. J . Lee. 1992. Genetic factors contributing to variation in litter size in British Large White gilts. Livest. Prod. Sci. 30:99-113.

J oakimsen, O., and R. L. Baker. 1977. Selection for litter size in mice. Acta Agric. Scand. 27:301-318.
J ohnson, R. K., G. R. Eckardt, T. A. Rathje, and D. K. Drudik. 1994. Ten generations of selection for predicted weight of testes in swine: Direct response and correlated response in body weight, backfat, age at puberty, and ovulation rate. J . Anim. Sci. 72: 1978-1988.

J ohnson, R. K., D. R. Zimmerman, and R. J . Kittok. 1984. Selection for components of reproduction in swine. Livest. Prod. Sci. 11: 541-558.

Kochera Kirby, Y., and M. K. Nielsen. 1993. Alternative methods of selection for litter size in mice: III. Response to 21 generations of selection. J. Anim. Sci. 71:571-578.

Lamberson, W. R., R. K. J ohnson, D. R. Zimmerman, and T. E. Long. 1991. Direct responses to selection for increased litter size, decreased age at puberty, or random selection following selection for ovulation rate in swine. J. Anim. Sci. 69:3129-3143.

Land, R. B., and D. S. Falconer. 1969. Genetics of ovulation rate in the mouse. Genet. Res. 13:25-46.

Neal, S. M., R. K. J ohnson, and R. J . Kittok. 1989. Index selection for components of litter size in swine: Response to five generations of selection. J. Anim. Sci. 67:1933-1945.

Ollivier, L. 1982. Selection for prolificacy in the pig. Pig News Info. 3:383-388.

Ollivier, L., and G. Bolet. 1981. La sélection sur la prolificité chez le porc: Résultats d'une expérience de sélection sur dix générations. J . Rech. Porcine Fr. 13:261-267.

Pérez-Enciso, M., and J. P. Bidanel. 1997. Selection for litter size components. A critical review. Genet. Sel. Evol. 29:483-496.

Ribeiro, E. L. de A., M. K. Nielsen, K. A. Leymaster, and G. L. Bennett. 1997. A simulation model including ovulation rate, potential embryonic viability, and uterine capacity to explain litter size in mice: II. Responses to alternative criteria of selection. J. Anim. Sci. 75:652-656.

SAS. 1996. SAS User's Guide (Release 6.09). SAS Inst. Inc., Cary, NC.

Schinckel, A. P., D. L. Lofgren, and M. E. Einstein. 1998. Recent stages index changes. Seedstock Edge, J uly Herdsire Issue: 120-121.

Smith, C. 1967. A note on the improvement of a trait by selecting on its components. Anim. Prod. 9:127-130.

van Engelen, M.A.J ., M. K. Nielsen, and E. L. de A. Ribeiro. 1995. Differences in pup birth weight, pup variability within litters, and dam weight of mice selected for alternative criteria to increase litter size. J. Anim. Sci. 73:1948-1953.

Young, L. D., R. K. J ohnson, and I. T. Omtvedt. 1977. An analysis of the dependency structure between a gilt's prebreeding and reproductive traits. I. Phenotypic and genetic correlations. J. Anim. Sci. 44:557-564.

Young, L. D., R. A. Pumfrey, P. J . Cunningham, and D. R. Zimmerman. 1978. Heritabilities and genetic and phenotypic correlations for prebreeding traits, reproductive traits and principal components. J. Anim. Sci. 46:937-949.

Zimmerman, D. R., and P. J. Cunningham. 1975. Selection for ovulation rate in swine: Population, procedures and ovulation response. J. Anim. Sci. 40:61-69. 